\title{
Pottery in the Funerary Context of El-Zuma Tumuli
}

\section{Timeline and Geographical Distribution of Vessels}

As mentioned in Chapter 2, we do not have much information about the period between the fall of the Meroitic Kingdom and the rise of the Kingdom of Makuria in the Dongola Reach. The time between the 4rd and 7 th centuries AD was a period of political and cultural transitions during which three Kingdoms came into being in Ancient Nubia: Nobadia in the north, Makuria in the middle, and Alwa in the south. In the Dongola Reach the main source of information about this period are burials. No contemporaneous habitation site has been discovered in the vicinity of the El-Zuma cemetery.

Because we do not have much information about this period, we should also look at the pottery from a historical perspective. Do we have continuity of Meroitic traditions or maybe earlier traditions? What changes in pottery can we observe, and what was new in the pottery assemblage?

The timeline of vessel types and their geographical distribution, as outlined in this chapter and illustrated in the accompanying figures and maps, is based on evidence from excavated or surveyed archaeological sites dated to the Meroitic to post-Meroitic period, which is presented in Chapter 2, and on analogies described in Chapter 3.6 (see Chapter 2, Table 2.1, Chapter 3.6, this volume).

\section{$1.1 \quad$ Cups}

[Figs 6.1 and 6.2]

Slipped and burnished cups of types I.1-I.4 are mainly dated to the post-Meroitic period and were widely distributed throughout the Dongola Reach region. Type I.1 seems to have been a long-lived form known since the Meroitic period. Such forms evolved from cups with tall and straight walls (Edwards 2004, 171, Fig. 6.9). In the El-Zuma graves these types are most common among the assemblage of complete cups. Type I.5 is not as well represented, but examples were found at other sites in the Dongola Reach, and they are probably imitations of short X-Group cups, usually decorated with two or three incised grooves on the lower part, just above the base, like the ones found at the grave Rom 32/1 (Mahmoud El-Tayeb and Czyżewska 2011, 116; Phillips 1987; Grzymski 1991), and the fabric suggests a Lower Nubian origin. Z14/14, Z14/11, Z14/8 and Z9/2, which were found in El-Zuma as solitary examples of their respective types, are also of Lower Nubian origin. Similar examples were found at Gerf Hussein, Karanog, Qasr Ibrim, Qustul, and Faras, and most of them are dated to the post-Meroitic period. Only one cup similar to Z14/14 was also found in the south, in Upper Nubia at Hamdab, and the timeline suggests that such cups had been known since the Meroitic period.

\subsection{Small Bowls}

[Figs 6.3 and 6.4]

Burnished and slipped bowls of types II.1-II.2, which were found in El-Zuma graves accompanied by burnished and slipped cups of types I.1-I.4, represent the same ware. The timeline for the use of both sorts of vessels is similar, but bowls had a much wider distribution in Ancient Nubia, especially across the southern part of the Dongola Reach, as observed at Hammur, El-Ghaddar, and ElKassinger (Klimaszewska-Drabot and Mahmoud El-Tayeb 2014, 11-12) and south of the Dongola Reach, between the Fourth and Sixth Cataracts. Only single examples have been discovered in Lower Nubia.

Bowls of types II.1 and II.2 testify to cultural continuity, originating in the Classic Meroitic period and remaining in production with continuous modifications until the Second Phase of the Early Makurian period. The simplest form was found at El-Kadada in a Meroitic burial. A larger variant of this vessel was discovered in the West Cemetery at Meroe (Dunham 1963, 189, Fig. 135c; 342, Fig. F). In the Dongola Reach, bowls of this type were found in a Late Meroitic burial at Hagar Sail, at the post-Meroitic cemetery in El-Kassinger Bahry, and in T.87 at Tanqasi (Klimaszewska-Drabot 2010a, 221, Fig. 3). Type II.3 probably shares the same timeline as types II.1 and II.2, but slightly differs from them in shape and technology. There is insufficient information from other sites to be able to recognize this type elsewhere.

Type II.4 should be considered as a new type of bowl which appeared in the post-Meroitic period. These small, red, wheel-made, grooved bowls were regularly deposited in graves in the Dongola Reach. They might be an imitation of metal bowls, similar in shape and also adorned with grooved decoration, examples of which were found in X-Group period graves at Ballana and Qustul (see Chapter 3.6, this volume). With slight modifications, these vessels remained in use until the Christian period. Grooved bowls became shallower with straight walls, and grooved decoration became more delicate. Examples of this type found at Selib 3, and dated to the 6th-early 7 th century $\mathrm{AD}$, could be interpreted as the successors of such bowls (Cedro 2017, 312-313). The same can be said of 


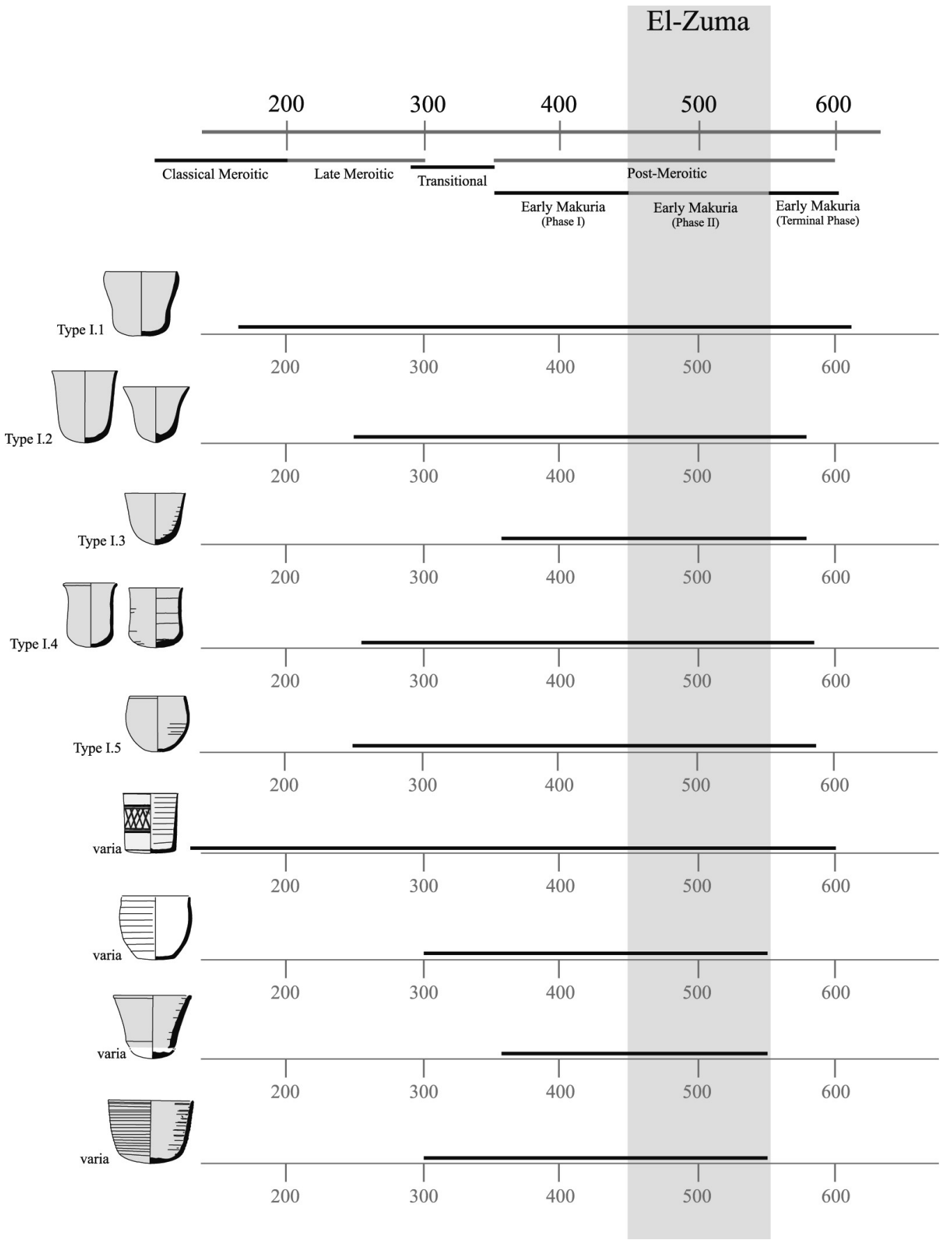

FIGURE 6.1 Dating of the cups in the El-Zuma repertoire ESTABLISHED BY E. CZYŻEWSKA-ZALEWSKA

examples found in Old Dongola and dated to the end of the 6th century and beginning of the 7 th century (Danys, n.d., 272, 274-275).

Types II.5 and II.6 are unique. Type II.5 has only ever been found at El-Zuma. The closest parallel comes from Sesebi in the Third Cataract region. These bowls may be an imitation of Egyptian vessels. The fabric suggests local production, but they can also be considered as a new type dated to the post-Meroitic period (see Chapter 3.6, this volume, Czyżewska-Zalewska 2016, 730). Type II.6 bowls were also rare among the vessels found in the tumuli at ElZuma, and possibly represent a new type of pottery, but they seem to be a little late, being dated to the Early Makurian and Christian periods. This type has no exact parallel from any other site in Nubia, but the closest analogies were found at Abkur in the Dongola Reach and slightly further north at Sesebi. The fabric suggests a Lower Nubian origin. 


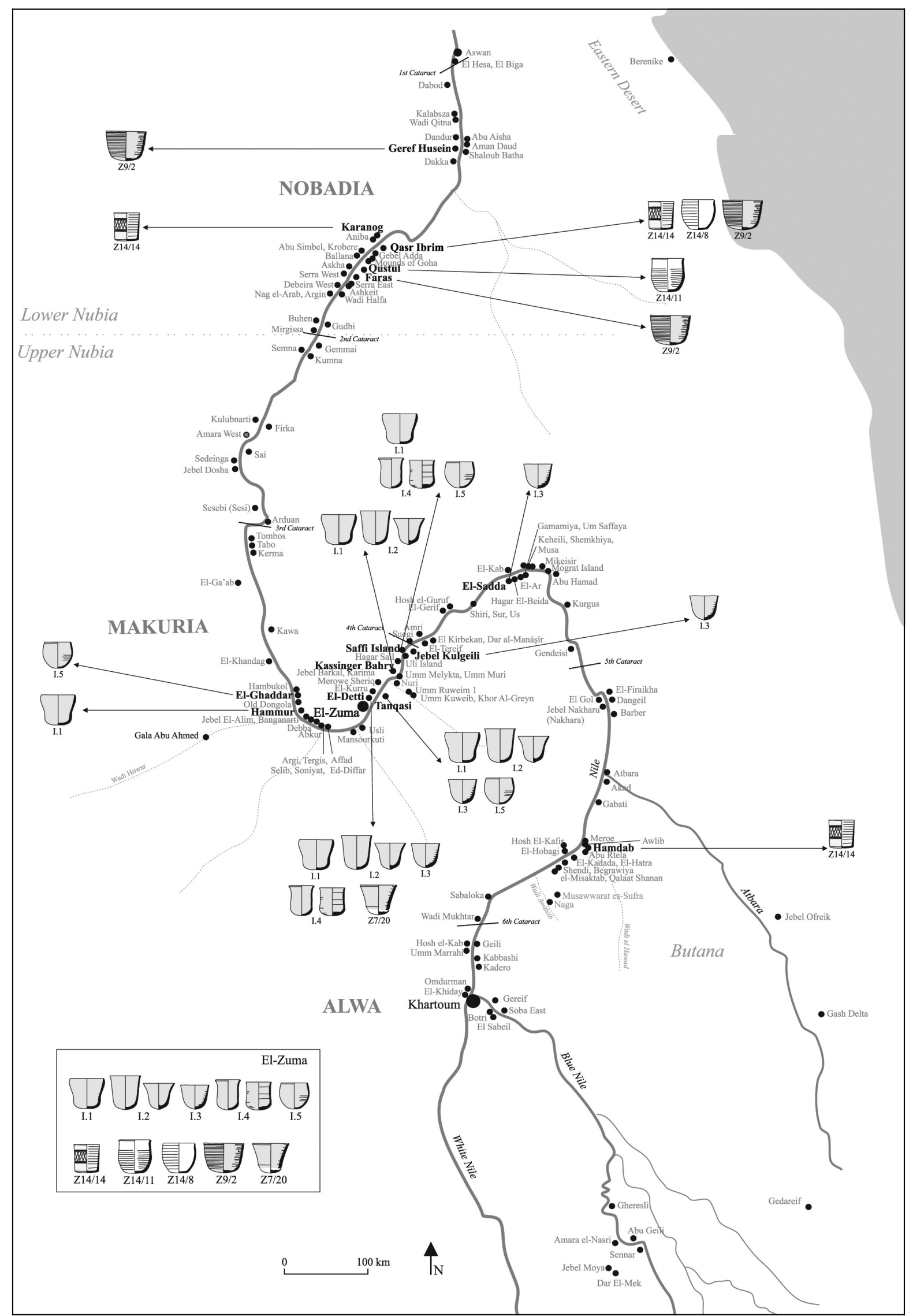

FIGURE 6.2 References and analogies to the cups from the El-Zuma repertoire IDENTIFIED BY E. CZYŻEWSKA-ZALEWSKA 


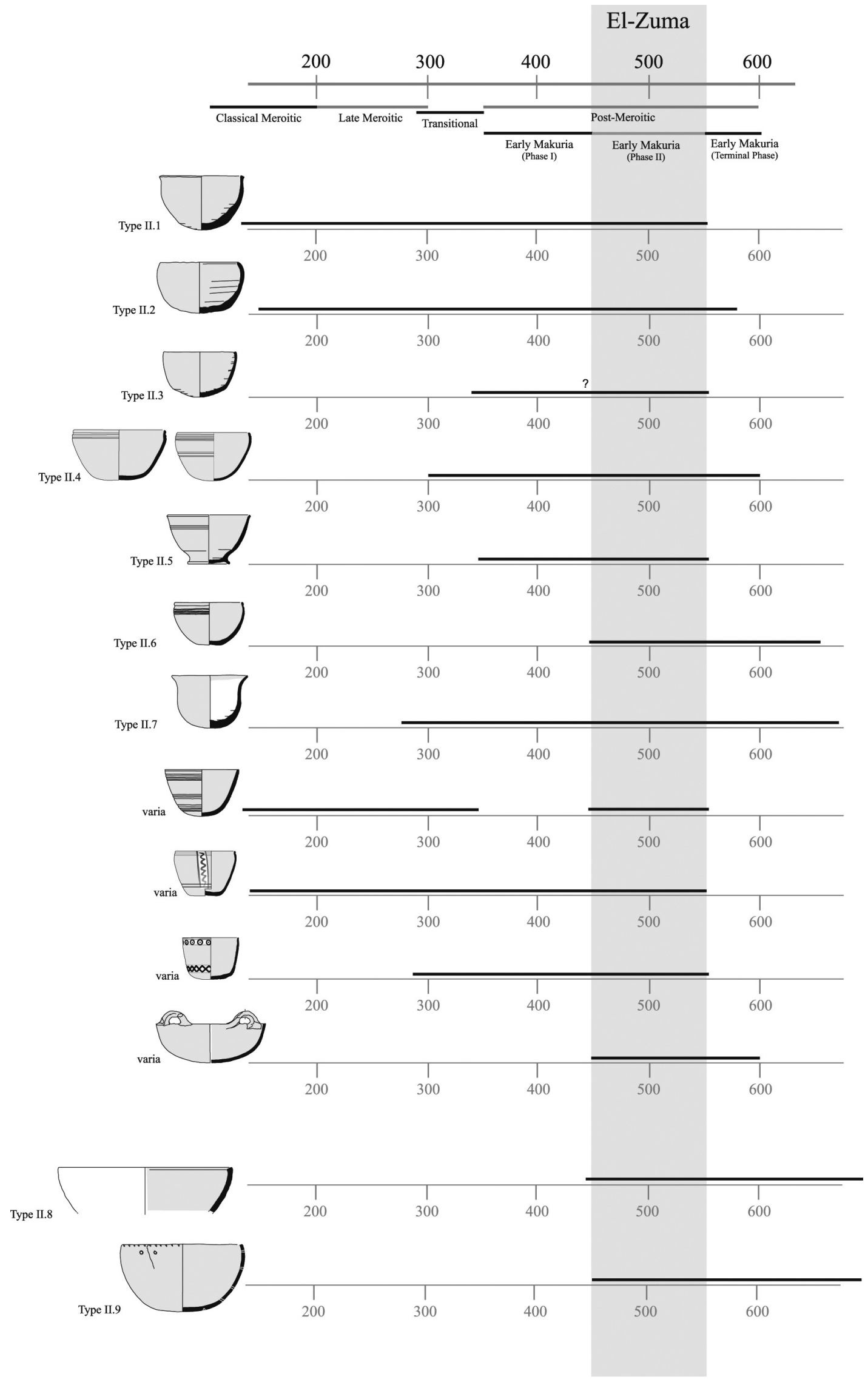

FIGURE 6.3 Dating of the bowls in the El-Zuma repertoire ESTABLISHED BY E. CZYŻEWSKA-ZALEWSKA 


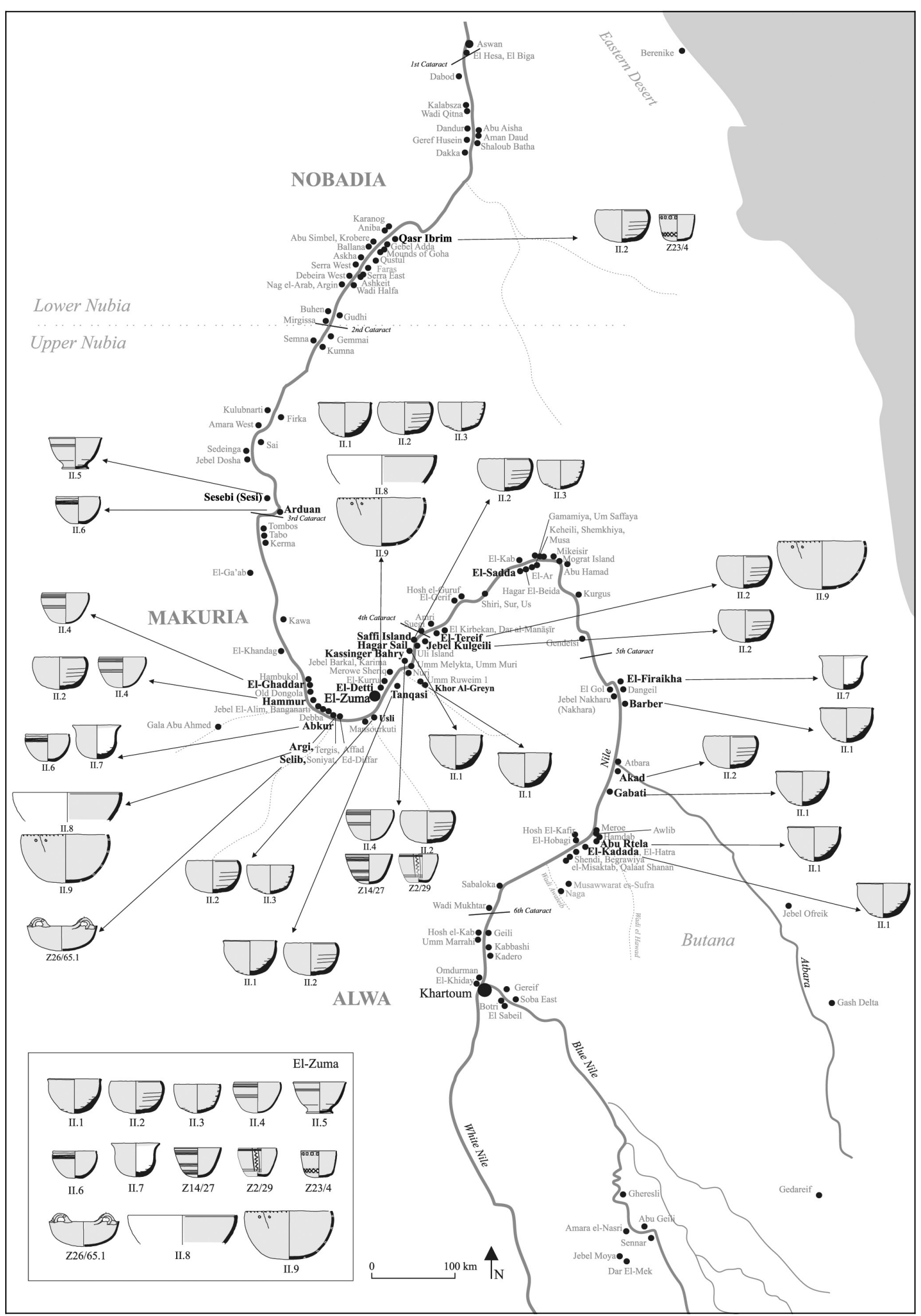

FIGURE 6.4 References and analogies to the bowls from the El-Zuma repertoire IDENTIFIED BY E. CZYŻEWSKA-ZALEWSKA 


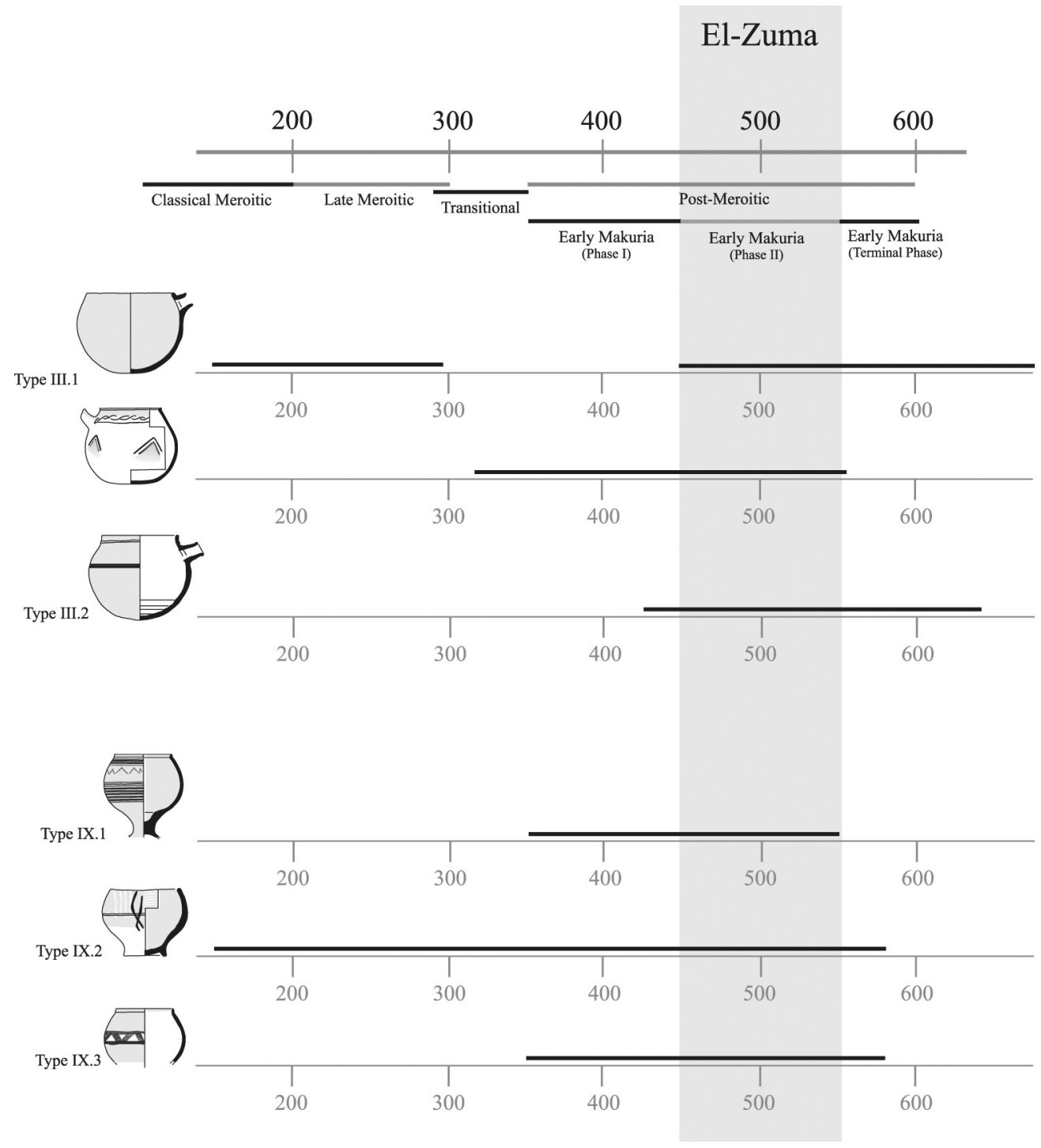

FIGURE 6.5 Dating of the spouted bowls and goblets in the El-Zuma repertoire ESTABLISHED BY E. CZYŻEWSKA-ZALEWSKA

Type II.7 is also uncommon. Small and large examples were discovered at the El-Zuma site. These vessels were probably of Late Meroitic origin and survived into the 7th century or even later. They are probably of Upper Nubian tradition. Examples were found in the Dongola Reach region and below the Fifth Cataract.

\subsection{Large Bowls}

[Figs 6.3 and 6.4] Large bowls of type II.9 were found in T.11 at El-Zuma. One example features a number of holes perforated on both sides of a long crack evidencing a repair, which implies that this vessel was used for a considerable span of time before being deposited in the burial. Animal bones found in situ inside the bowl suggest that it was used for serving food (Mahmoud El-Tayeb and Czyżewska 2011, 117). Such bowls are generally dated from the Early Makurian to the
Christian period. Most of the large bowls in the El-Zuma repertoire are connected with plundering activity and were re-used as scrapers or digging tools (see Chapter 5 , this volume).

\subsection{Goblets}

[Figs 6.5 and 6.6]

Goblets are not common in the El-Zuma repertoire; they are represented by only three examples. The most prevalent is type IX.2, which has a long tradition dating back to the Meroitic period. This type was also popular in the postMeroitic period, with examples recorded at Lower Nubian cemeteries dated to the 4th-6th centuries. Their sparse representation in the Early Makurian pottery at El-Zuma suggests that they may have been less popular in the Dongola Reach during the 5 th-6th centuries. 


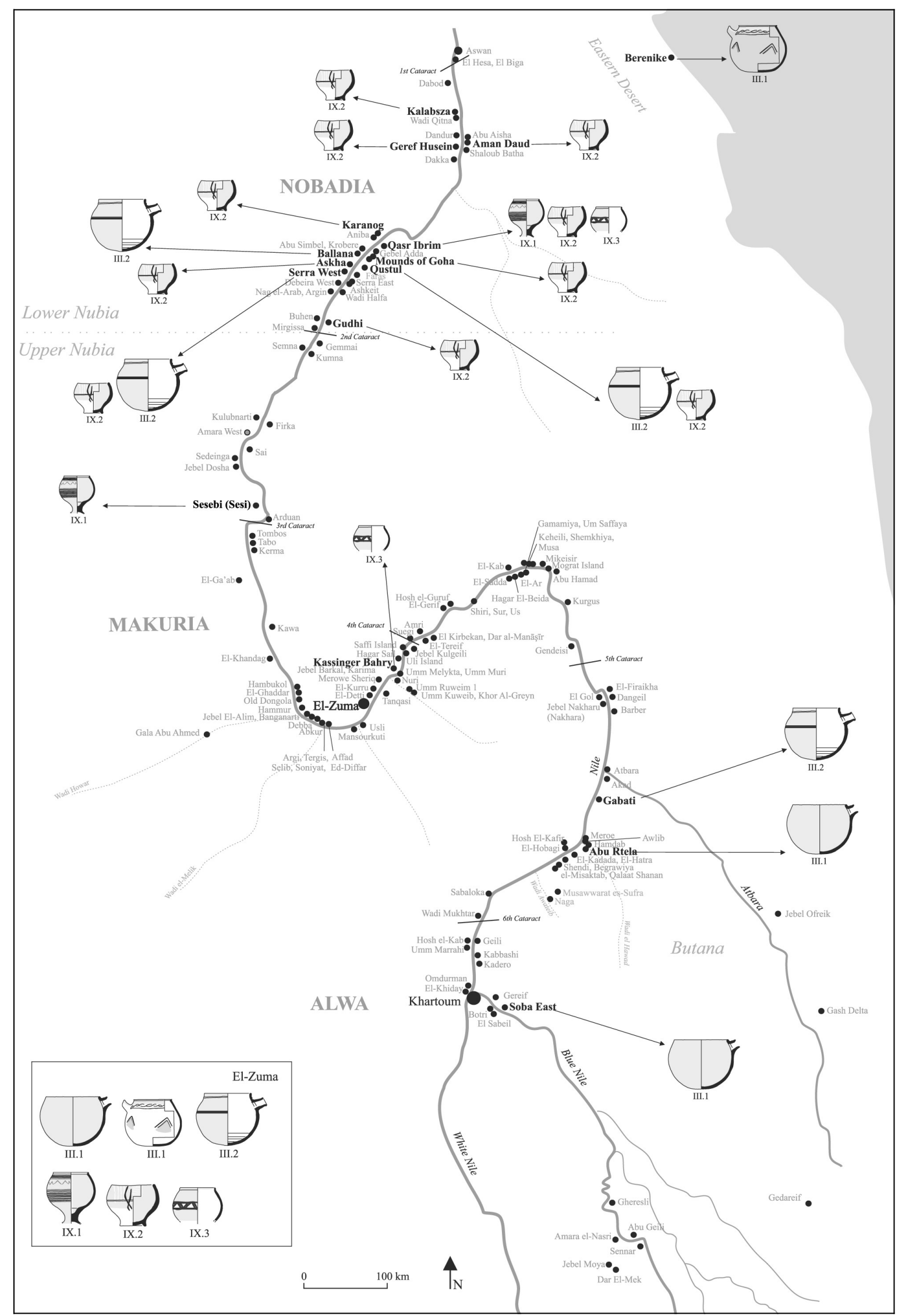

FIGURE 6.6 References and analogies to the spouted bowls and goblets from the El-Zuma repertoire IDENTIFIED BY E. CZYŻEWSKA-ZALEWSKA 


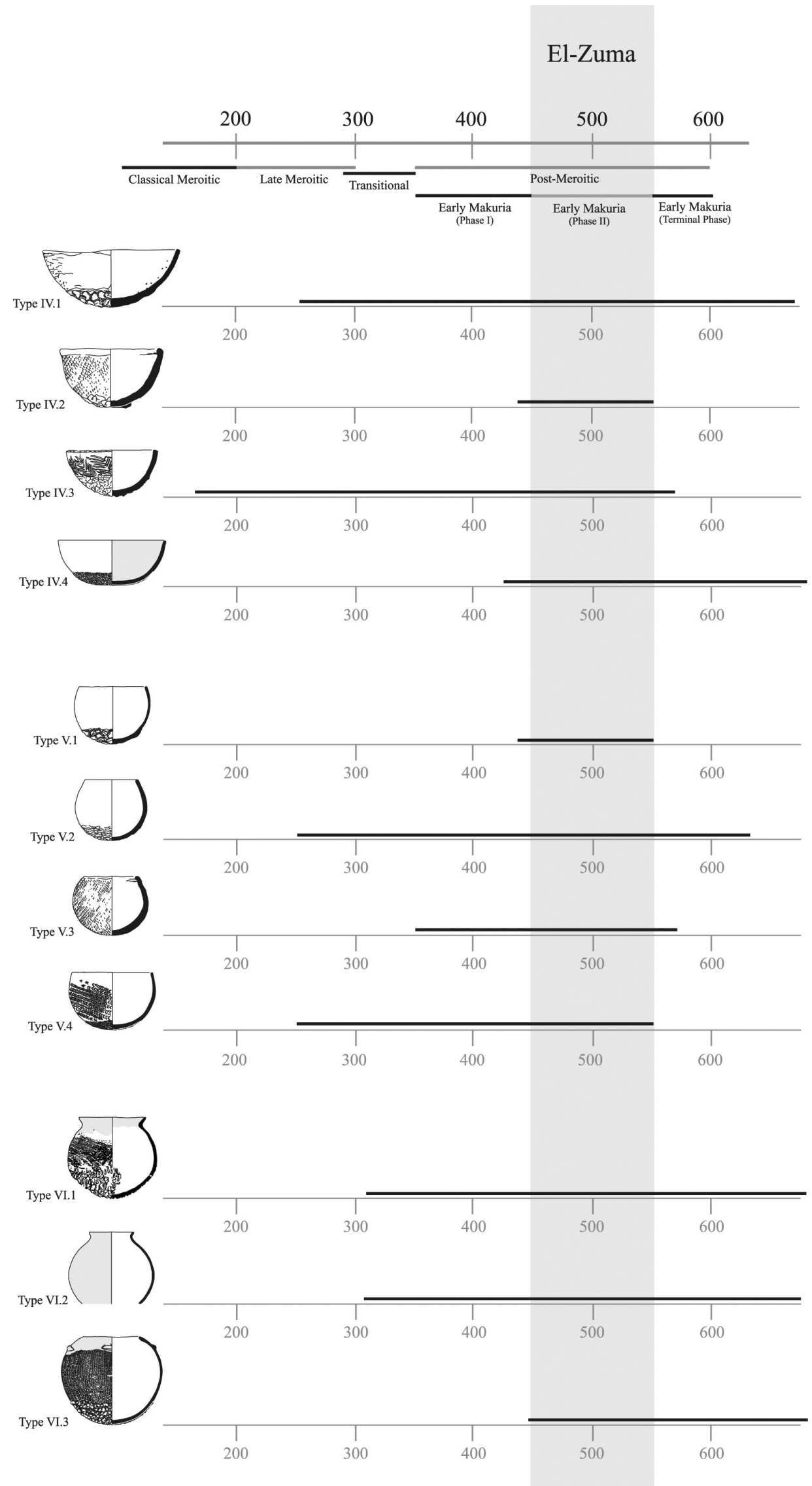

FIGURE 6.7 Dating of the bowls and pots in the El-Zuma repertoire ESTABLISHED BY E. CZYŻEWSKA-ZALEWSKA 


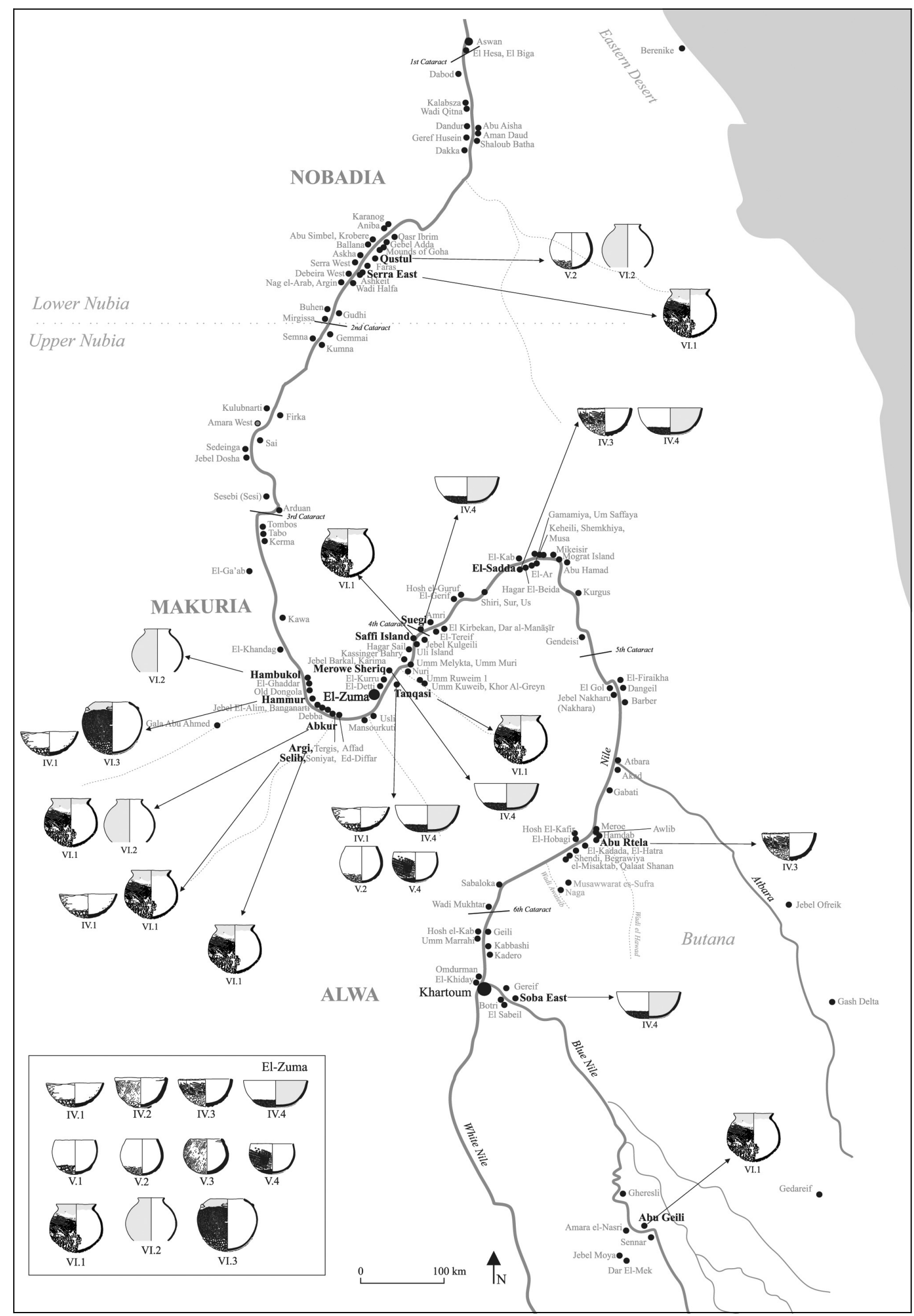

FIGURE 6.8 References and analogies to the bowls and pots from the El-Zuma repertoire IDENTIFIED BY E. CZYŻEWSKA-ZALEWSKA 


\subsection{Spouted Bowls}

[Figs 6.5 and 6.6]

These spouted bowls occur in open and closed forms. According to Mahmoud El-Tayeb, the closed form was less popular and the open one was more common and noted in El-Zuma graves. Spouted bowls were known in Nubia in the Neolithic, throughout the Kerma and Meroitic periods up to the post-Meroitic period (Mahmoud El-Tayeb 2012, 101). As mentioned above (see Chapter 4 , this volume), the exact function of this vessel is unclear. It may have been used in beer production or in purification ceremonies. Examples similar to type III.1 are dated to the Classic Meroitic and Late Meroitic periods. They were also discovered in post-Meroitic and Early Christian period contexts and seem to be connected with a southern tradition (South of Dongola Reach). Similar examples were found at Abu Rtela and Soba East. One example of this type was an import from the Eastern Desert. An almost identical vessel was discovered in Berenike, Egypt. Type III.2 seems to represent a northern tradition. Bowls of this type were found in Lower Nubia at Ballana, Qustul, and Serra West, while in the south similar vessels are known only from Gabati. As mentioned earlier, these jars were probably imitations of metal vessels. Bronze examples were discovered in Ballana and Qustul and are dated to the post-Meroitic period.

\subsection{Bowls and Pots-Kitchen Ware}

[Figs 6.7 and 6.8]

These vessels differ in size, but they share some common features. They are all handmade with an extra layer of clay added at the base and pitted in order to disperse heat. The external surface of some of these forms is occasionally covered with a mat-impressed pattern. In some cases, the inner surface and rim are coated with red slip and burnished. Such bowls with a layer of clay added to the base are known in a variety of sizes, and are globular or shallow and hemispherical in shape. Examples have been found at other cemeteries such as Tanqasi (Klimaszewska-Drabot 2008, Fig. 14; 2010a), and Hammur (Phillips and Mahmoud El-Tayeb 2003, Pl. 7). They are very characteristic of the post-Meroitic period, especially in the Dongola Reach (see Fig. 6.8), but occur less frequently in Lower Nubia (Williams 1991, Figs 185, 121) and south of the Dongola Reach area (Edwards 1998, I:178-193; Klimaszewska-Drabot and Mahmoud El-Tayeb 2014, 13). As mentioned earlier (see Chapter 3.6, this volume), shallow bowls are probably of Napatan tradition and survived throughout the Meroitic period to the post-Meroitic. Bowls of types IV.1 and V.1 are known from Classic and Late Meroitic period sites, while types IV.2 and IV.4 seem to be later and are dated to the Early Makurian period. Dokat (IV.4) appeared in the Meroitic period; they were found in all Late Meroitic phases at Umm Muri, dated to between the 2nd-3rd cen- tury AD and the Early Christian period (Thomas 2008, 6566, 68-70, Figs 3.1, 3.7,8). In pots of group V, types V.2 and V.4 originated in the Late Meroitic period and remained in use up to the Christian period, while types V.1 and V.3 seem to be later types introduced in the Early Makurian period. Type vi pots also represent a long-lived tradition. They occur from the Transitional to the Christian period, but in the El-Zuma repertoire this type of pot was recorded outside the burial chambers, mainly in the fill of shafts or tumulus superstructures.

\subsection{Jars and Bottles}

[Figs 6.9 and 6.10]

Jars and bottles of group viI were very common across the whole of the Dongola Reach in post-Meroitic and Early Makurian graves.

Jars and bottles of types VII.1-VII.4 are of Meroitic origin. Their wide distribution extends beyond the Dongola Reach into areas further south between the Fourth and Sixth Cataracts.

Mat-impressed vessels are represented in every type of jar in the El-Zuma repertoire, but they are not very common. Among the 225 complete or almost complete jars, 25 have mat impressions on the body, and these vessels originated in the Meroitic period (see Fig. 6.9). Jars with a long, broad neck, usually red-slipped and with a smoothed and burnished globular body or a rough, undecorated surface, are characteristic of the Early postMeroitic period (c. AD 350-450) and are more common in the El-Zuma assemblage. They seem to be of later origin, and are dated to the Late Meroitic or Transitional period. Mat-impressed vessels are more common among these types (20 examples were recorded) than among types VII.5 and VII.6.

Handmade beer bottles with an ovoid body (types VII.5 and VII.6), a relatively long, narrow neck and a mouth with a flared rim occur in the Transitional and Early Makurian periods. Variants with mat-impressions are present but are not as prevalent as other types (only 5 examples were recorded). The two distinctive bosses or loops placed symmetrically opposite one another seem to be an evolution of the numerous bosses applied as decoration on the shoulders and neck of jars of the Meroitic and postMeroitic periods. It seems that such decoration was limited to only two bosses on the shoulders in the Early Makurian period, and the new applied loop detail appears in the Early Makurian period (VII.6d). Among the $225 \mathrm{com}-$ plete or almost complete vessels, 33 feature decoration in the form of applied bosses. Most of them (27 examples) belong to types VII.5 and VII.6, with five examples classified as type VII.2, and one as type VII.4. Bosses of this sort are present on vessels without mat-impressed patterns. 


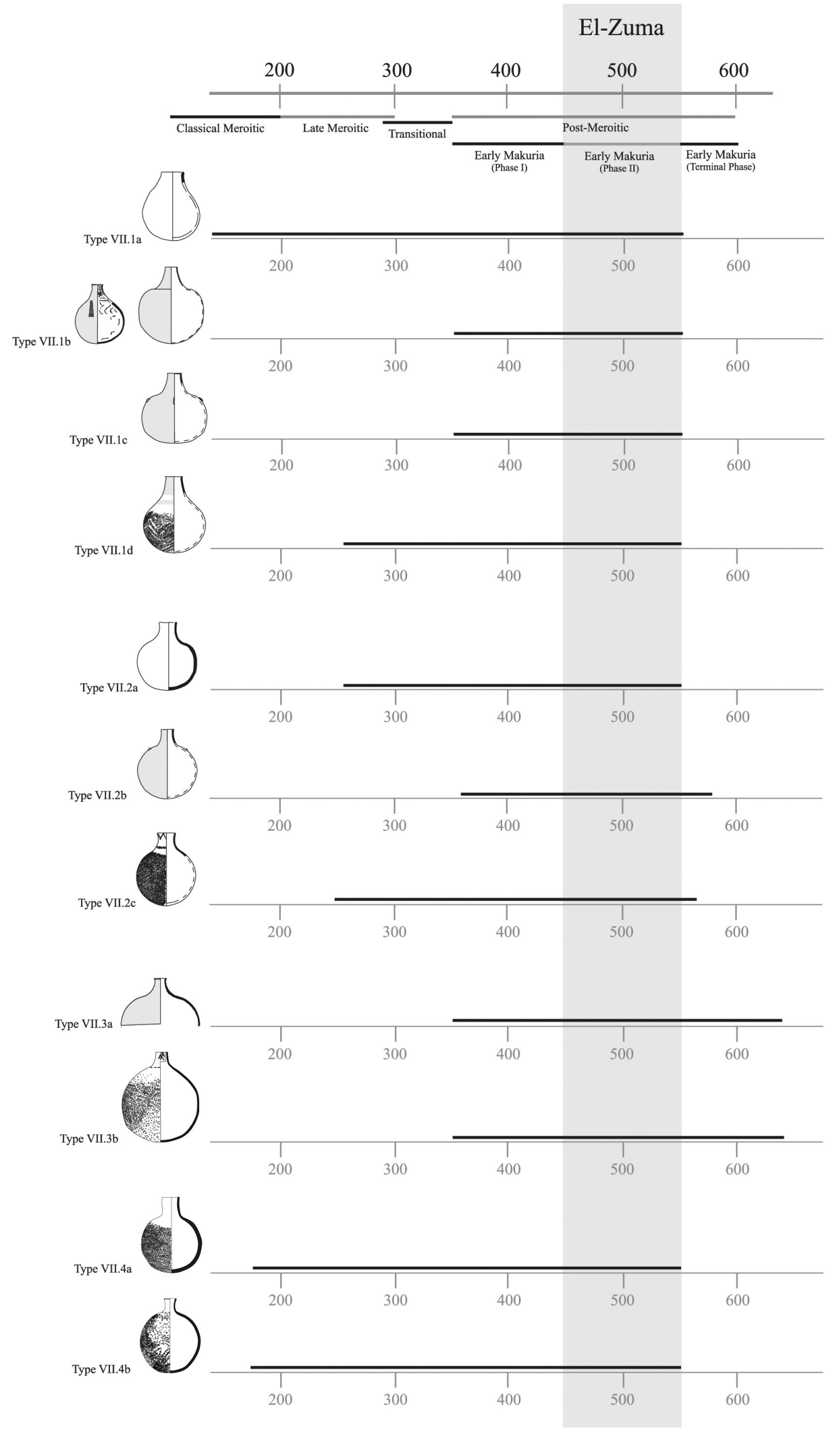

FIGURE 6.9A Dating of the jars and bottles in the El-Zuma repertoire ESTABLISHED BY E. CZYŻEWSKA-ZALEWSKA 


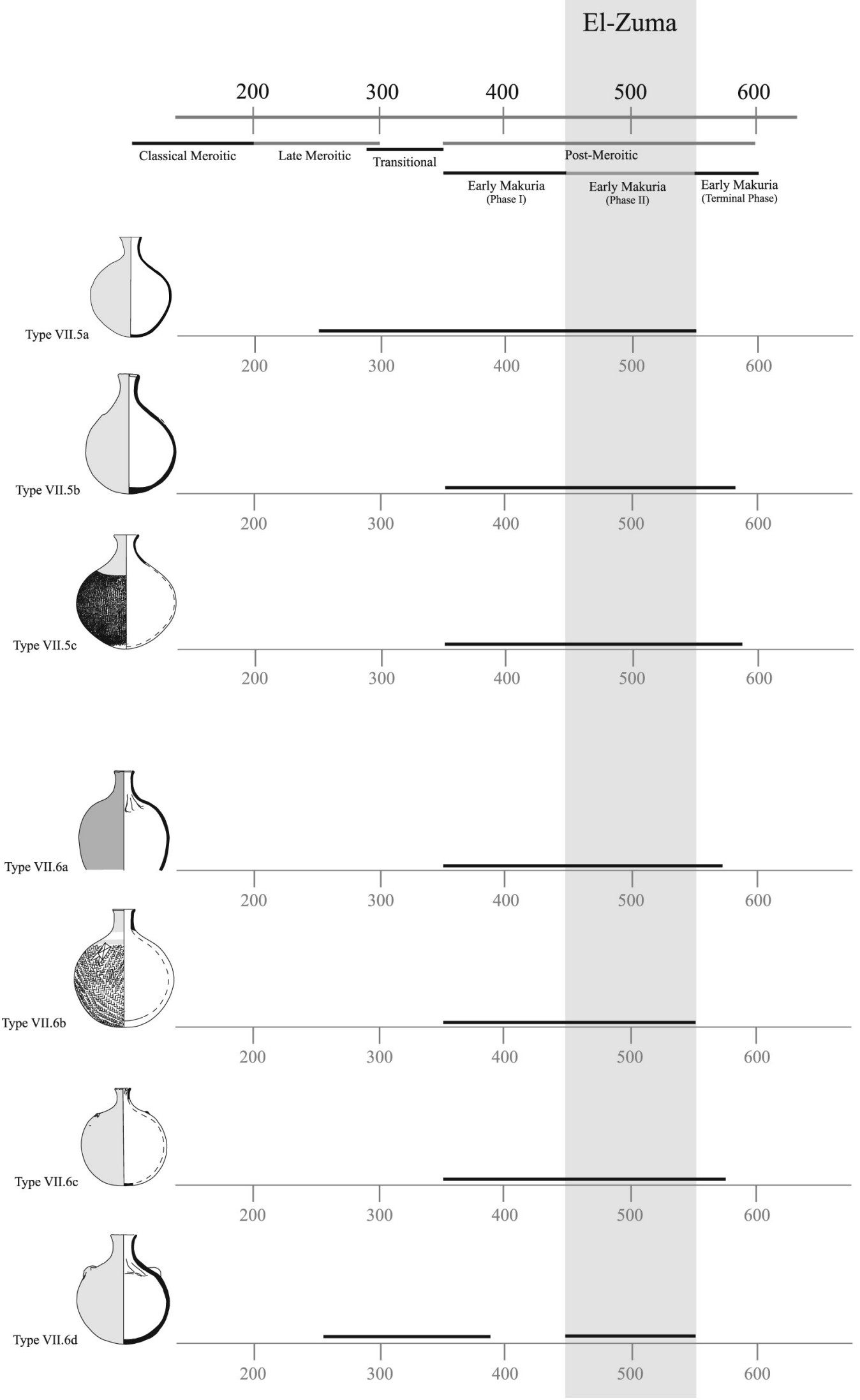

FIGURE 6.9B Dating of the jars and bottles in the El-Zuma repertoire ESTABLISHED BY E. CZYŻEWSKA-ZALEWSKA 


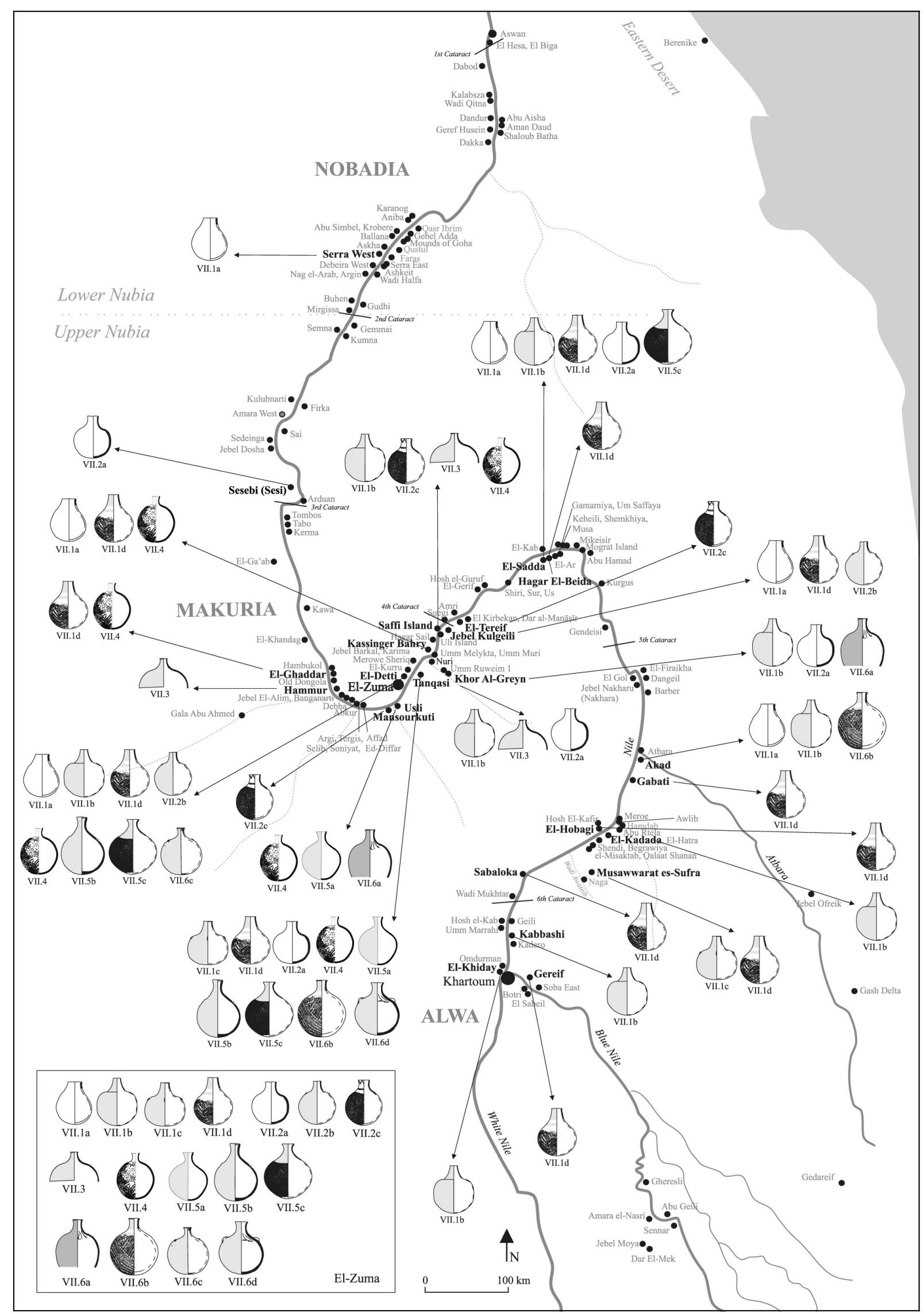

FIGURE 6.10 References and analogies to the jars and bottles from the El-Zuma repertoire IDENTIFIED BY E. CZYŻEWSKA-ZALEWSKA 


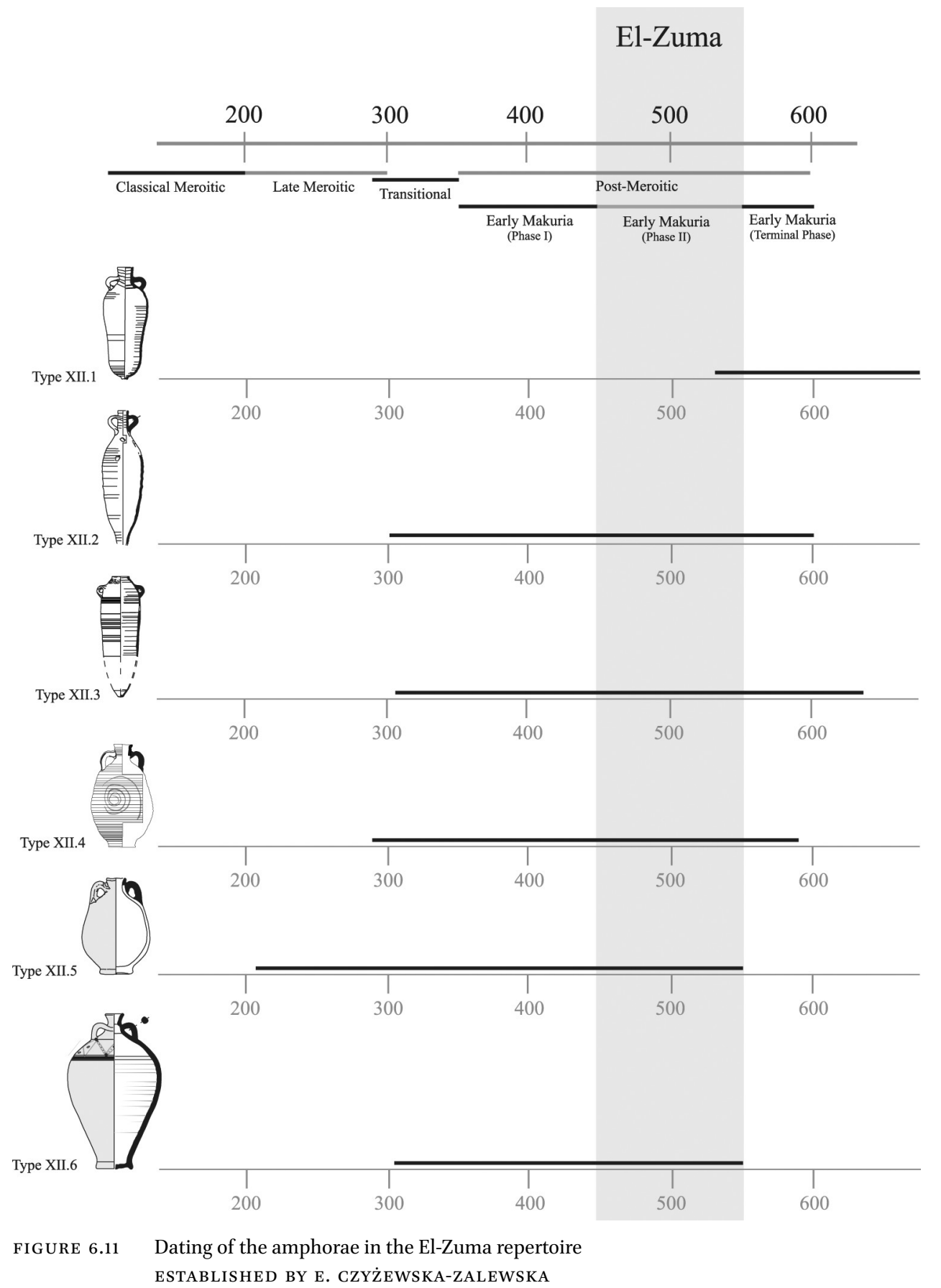

Group VII jars have been found at various sites in Upper Nubia, which points to the spread of the southern tradition of pottery making (Mahmoud El-Tayeb 1998, 37). Mahmoud El-Tayeb suggests that they were probably first manufactured in workshops in the Shendi Reach (Mahmoud El-Tayeb 2012, 86).

\subsection{Amphorae}

[Figs 6.11 and 6.12]

Transport and table amphorae represented in the El-Zuma repertoire are imports from Old Dongola, Lower Nubia, and Egypt. These amphorae appear in graves of the Tran- sitional period. They were found in small number in the El-Zuma tumuli, and were not a regular feature of burial goods in the Dongola Reach. Amphorae were common in graves in Lower Nubia (see Fig. 6.12). A few examples of Dongolan amphorae indicate that the El-Zuma necropolis was still in use during the early days of Old Dongola.

\subsection{Bottles and Jugs}

[Figs 6.13 and 6.14]

Bottles and jugs are represented in small number in the El-Zuma repertoire and are unique in the Dongola Reach 


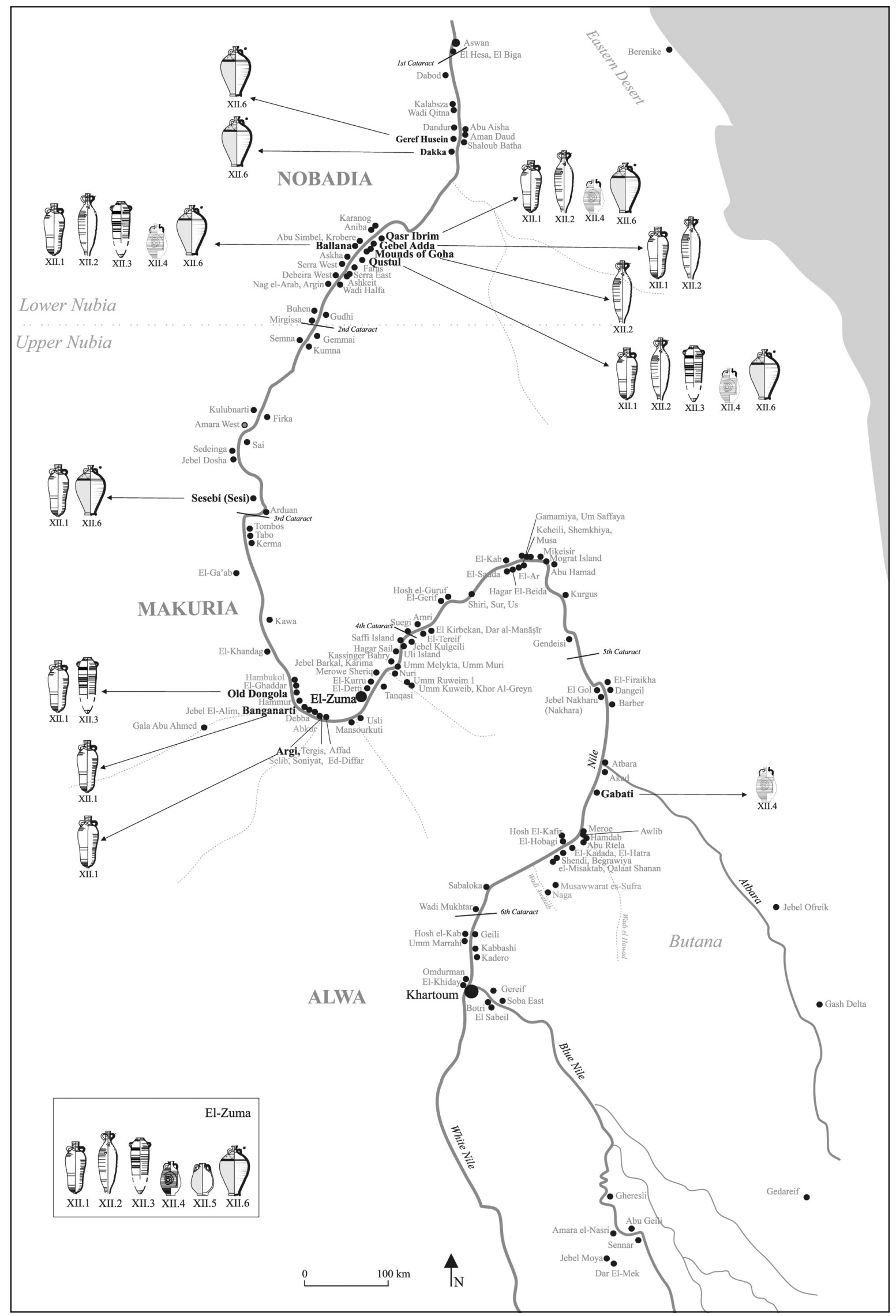

FIGURE 6.12 References and analogies to the amphorae from the El-Zuma repertoire IDENTIFIED BY E. CZYŻEWSKA-ZALEWSKA 


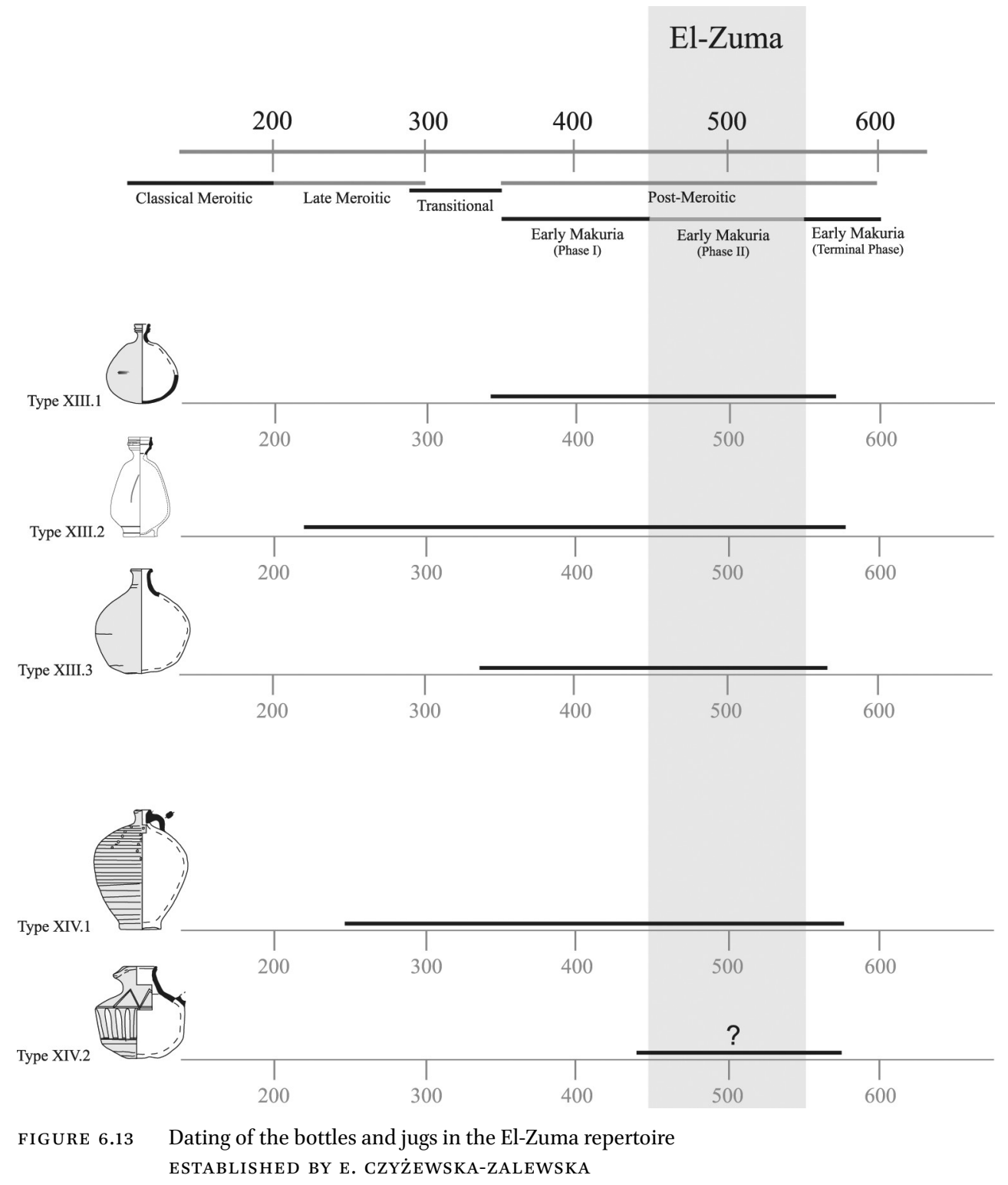

region. Like amphorae, they were imports and are connected with Lower Nubian traditions. They are known from the Late Meroitic and Transitional periods. Examples were discovered mainly at Lower Egyptian cemeteries such as Ballana, Qustul, Serra West, and Gebel Adda. In Upper Nubia they were recorded at El-Zuma and Gabati (see Fig. 6.14).

\subsection{Lamps}

[Figs 6.15 and 6.16]

Lamps in the El-Zuma repertoire are most probably associated with grave looting (as mentioned in Chapter 4). They were discovered inside the tunnels, close to the walls or, for example, at the top of the fill of the tunnel, and are dated from the Early Makurian to the Christian period. Lamps were more commonly represented in Lower Nubian repertoires. They also occur in the Dongola Reach region, espe- cially at Christian sites. Further south, vessels of this type are almost entirely absent.

1.11 Qawadis

[Figs 6.15 and 6.16]

Jars used in conjunction with the saqiya waterwheel were introduced in Ancient Nubia during the Late Meroitic period. In the El-Zuma repertoire they are connected with the activity of grave robbers or maybe grave builders, but did not serve as grave goods. Most sherds of these vessels were used as scrapers, and were found in tumulus superstructures and the fills of shafts and tunnels. Vessels similar to those excavated at the El-Zuma cemetery are dated from the Early Makurian to the Christian period and were mainly discovered at settlements, but are virtually unknown as grave goods. 


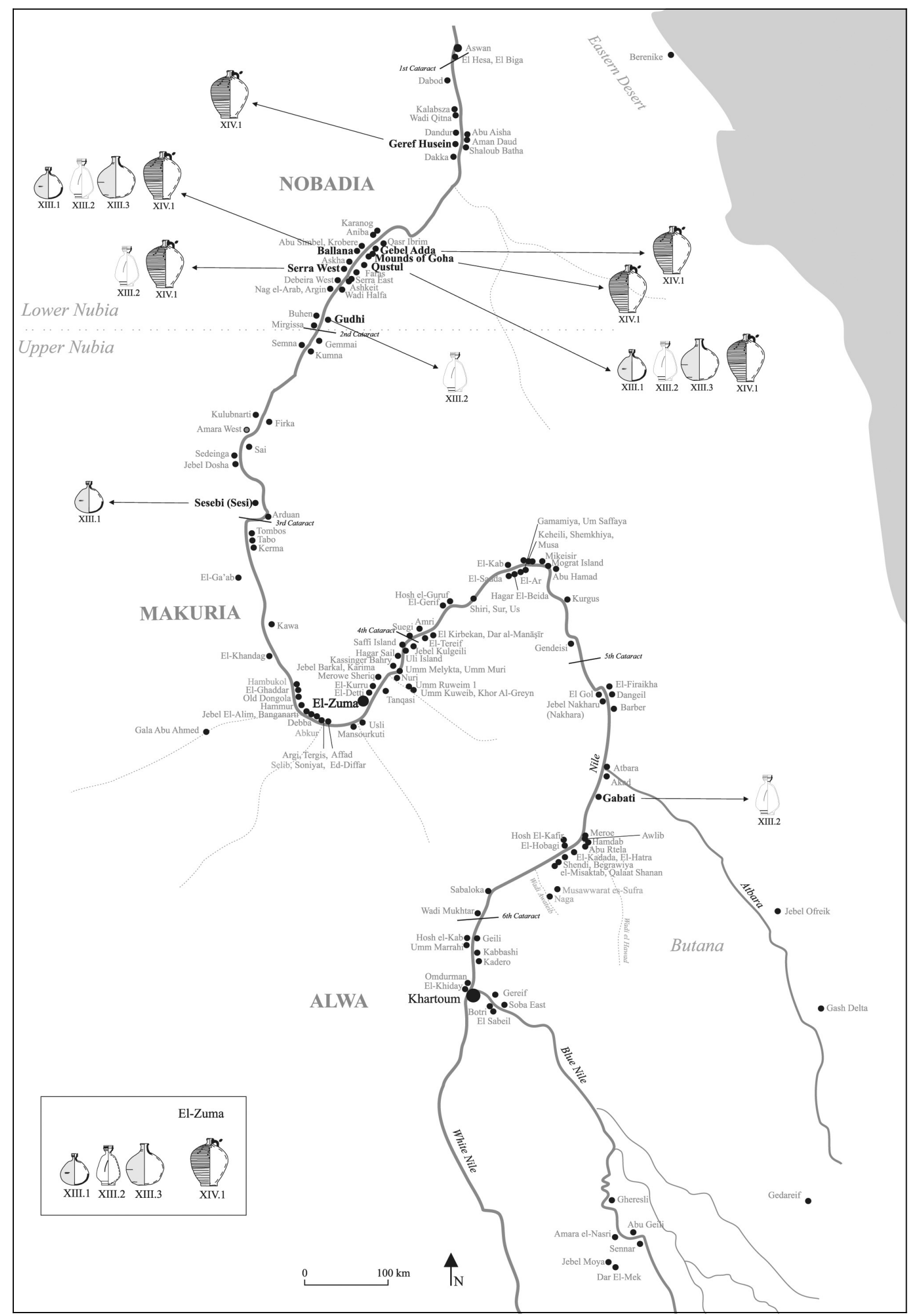

FIGURE 6.14 References and analogies to the bottles and jugs from the El-Zuma repertoire IDENTIFIED BY E. CZYŻEWSKA-ZALEWSKA 


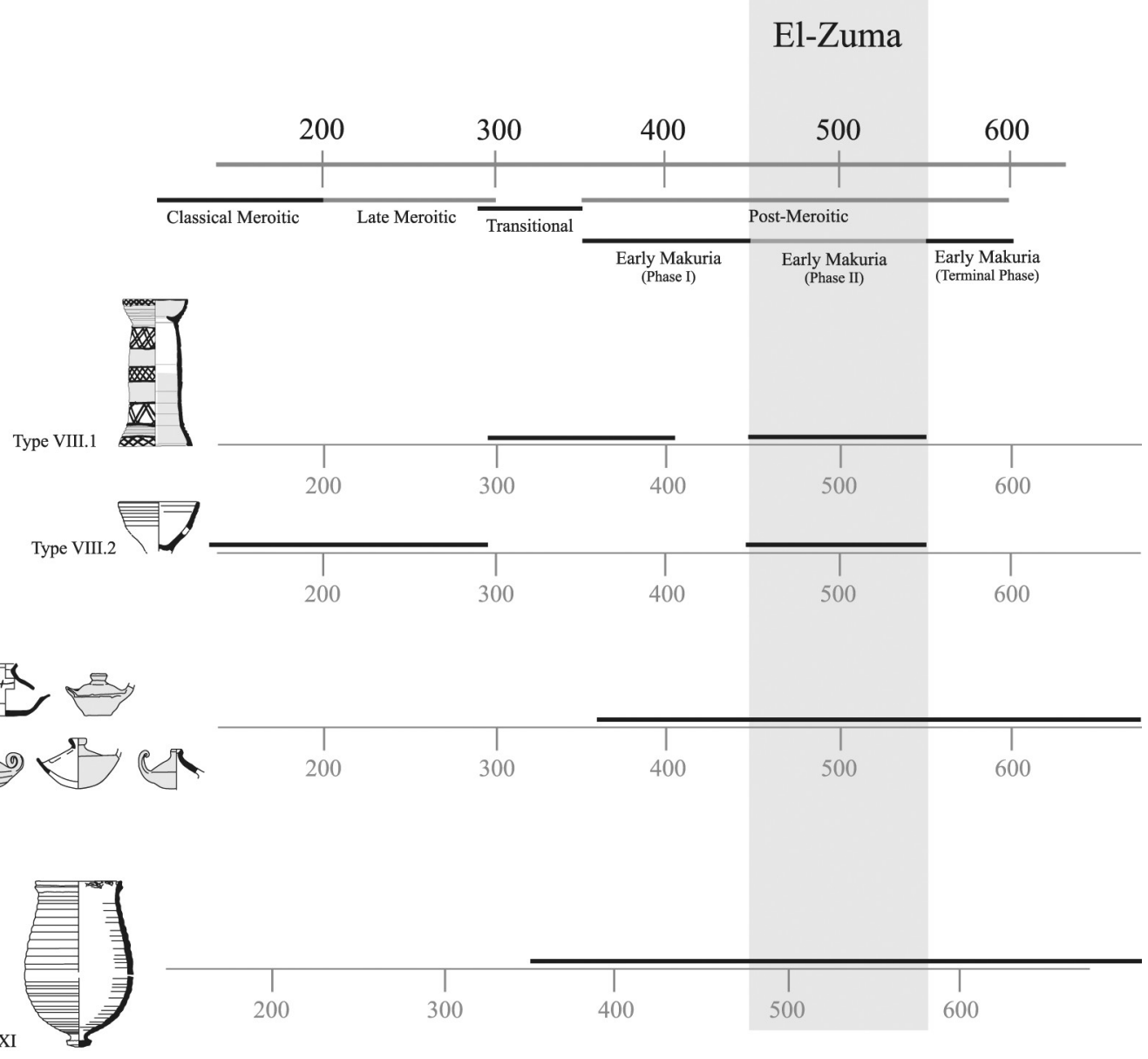

FIGURE 6.15 Dating of the specialized vessels in the El-Zuma repertoire ESTABLISHED BY E. CZYŻEWSKA-ZALEWSKA

1.12 Stands

[Figs 6.15 and 6.16] Stands are very rare at the El-Zuma cemetery. Single examples, probably of Meroitic origin, were discovered there. They are equally uncommon at other archaeological sites of the post-Meroitic period.

\section{2}

\section{Pottery as Grave Goods}

The use of pottery as containers for grave goods was connected with burial customs in which food and drink played a significant role.

From 4500 вС the occurrence of different types of drinking vessels like small cups, beakers, and goblets increases. The occurrence of both plain and decorated drinking vessels indicates a difference in what was consumed by commoners and the elite. Elaborately shaped ceramic vessels were most likely used for serving drinks such as beer on festive occasions (Haaland 2012, 332333). Reliefs from temples and tomb chapels, as well as painted designs on some ceramics, depict the use of wine and wine amphorae in religious and funerary rites. Evidence for the large-scale consumption of beer increased during the Kerma period, but is more evident during the Meroitic period and manifest in a number of massive deposits of broken jars, as well as smaller bowls and cups, on hilltop locations in the Meroe area (Haaland 2012, 335336).

An important factor in the consumption of beer was the innovation of the saqiya. In Lower Nubia during the Meroitic period, the use of the saqiya led to an increase in the cultivation of wheat and barley in the winter season, and sub-Saharan crops such as sorghum in the summer season (Fuller 2014, 165). Further south, sorghum was discovered at Meroe, Dangeil, and Abu Geili. According to Edwards (2004), sorghum was important in the Meroitic period and was associated with making beer, which was stored in jars (Fuller 2014, 169-171). The consumption of beer had important health benefits because it contained antibiotic tetracycline. Beer was made from grain kept in mud stores where it became contaminated by the bacterium Streptomyces, which produces tetracycline, 


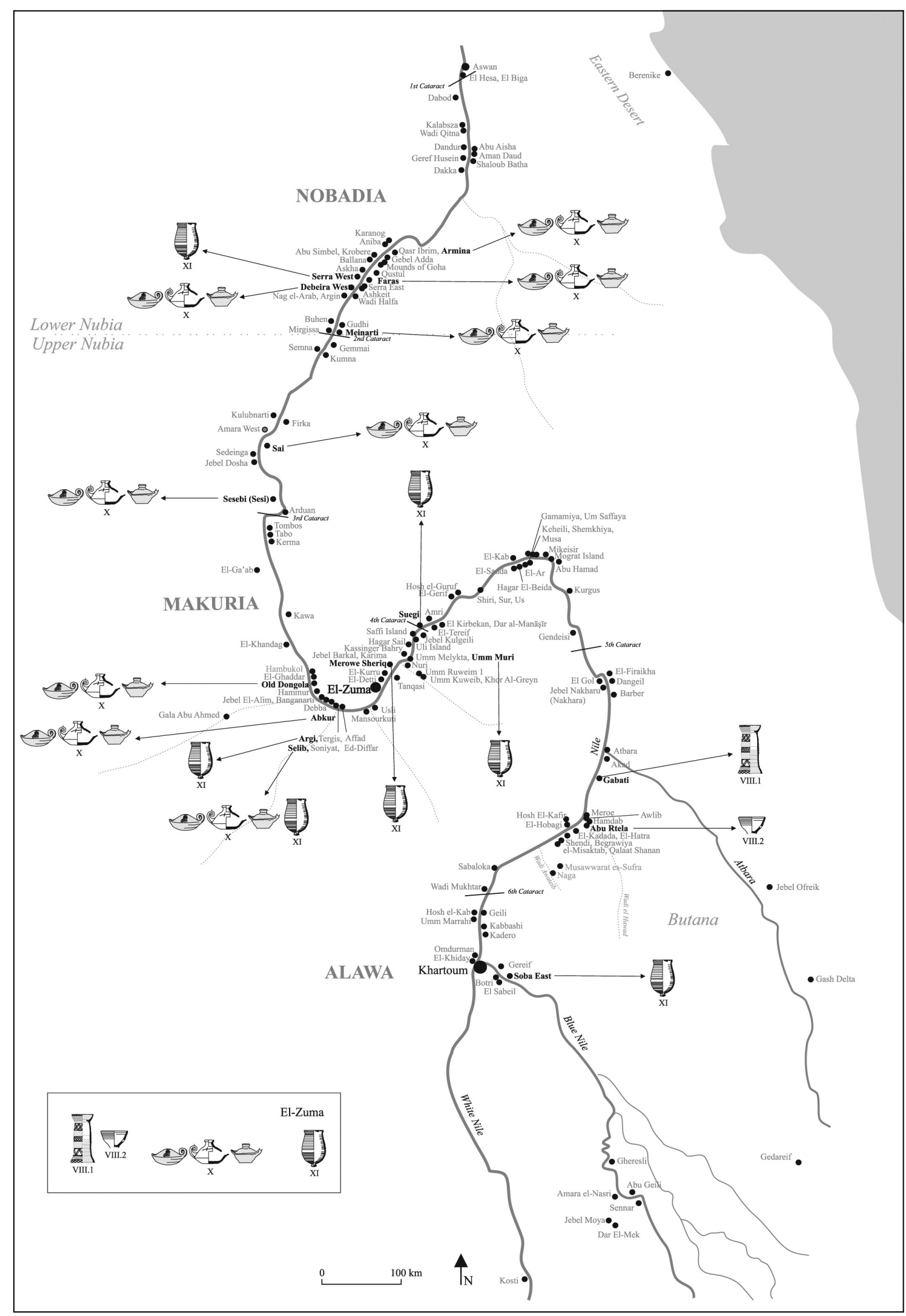

FIGURE 6.16 References and analogies to the specialized vessels from the El-Zuma repertoire IDENTIFIED BY E. CZYŻEWSKA-ZALEWSKA 
which is why beer was probably important both nutritionally and medically (Haaland 2012, 333-334). The origins of Nubian sorghum are obscure, but it had been known since Neolithic times. In the Meroitic period sorghum had a symbolic meaning and was depicted as one of the divine rewards or was depicted in the hand of a god, as seen in a royal burial at Qustul dated to the post-Meroitic period (Fuller 2014, 169-171).

Food is represented, together with beverages, in the burial customs at El-Zuma. Animal food offerings were found in a large number of tumuli at this site (see Volume I, Chapter 8), but agrarian products were noted only in small quantities. Some vegetable matter was recorded in T.5, and basket remains with seeds (seed analysis in preparation) were discovered in T.26 (see Volume III, Chapter 18).

Other interesting aspects worth mentioning here are the evidence of fire noted in grave contexts and the question of ceremonial feasts. Traces of fire have been recorded in some Meroitic and post-Meroitic burials in the Dongola Reach and the Fourth Cataract area, as well as further south (Lenoble 1994, 95-96). Pieces of charcoal and burnt bones were sometimes found in and around the hearth area. Lenoble suggested that meat had been cooked and consumed during the inhumation process, and before the burial was finally sealed, as part of a "Funerary Banquet" (Lenoble 1994, 95-96). At El-Zuma, pieces of charcoal were found on the top surface of the pier in T.25, and at the bottom of the external shaft of the tunnel in T.5. Fires may have been used to purify the burial chamber before depositing a body in it or to provide a source of light for grave robbers. In Mahmoud El-Tayeb's opinion, burial purification seems to be the most acceptable interpretation for the existence of hearths in or around the grave shaft (Mahmoud El-Tayeb 2012, 9, 83-84). Another interesting phenomenon observed in the tumuli at ElZuma was the accumulation of pottery left in the shaft rather than in any of the grave chambers. Pottery was found deposited inside the shaft together with animal bones in T.12 (see Volume I, Chapter 3, Fig. 3.45). The placement of ceramic vessels outside burial chambers was recorded in earlier times, in the Kerma period, when large deposits of pottery were left both inside graves and on the surface. Masses of sherds, sometimes associated with burnt animal bones, that probably accumulated over an extended period were almost certainly deposited during ceremonial feasts and sacrifices (Haaland 2012, 335336).

The ceramic assemblage from El-Zuma is discussed here by examining three main aspects: pottery as vessels for serving food and drink; pottery as evidence of burial customs, rituals, and traditions; and pottery as evidence of grave building or looting activity.

In the first instance, the consumption and serving of food are attested by the presence of cups, goblets, and small bowls. Food, consisting mainly of small pieces of meat, was deposited in the burial chamber in bowls and cups (see Chapters 4 and 5 , this volume; Volume I, Chapters 3 and 8). It is interesting that vessels of types IV-V featured among the grave goods. Their diversity in shape and size suggests that they may have been used not only for cooking; in grave contexts they could be interpreted as vessels for serving food. The presence inside the tumuli of storage containers, such as jars and bottles, amphorae (probably for wine) and large bowls used as storage vessels, can be interpreted as a means of providing the deceased with supplies for the afterlife. Small bottles, jugs, and maybe small amphorae were probably part of the personal equipment of the deceased.

In the case of rituals, religion, and burial customs, it is difficult to recognize these practices in the archaeological record. Pieces of charcoal found on the pier in T.25 and at the bottom of the external shaft of the tunnel in T.5, or the accumulation of pottery left in the shaft, may suggest some kind of funerary customs. The symbols scratched on some vessels could have had protective and magical meanings associated with beliefs.

In the third case, looking at pottery as evidence of grave building or looting activity, discussion focuses on lamps and digging tools or scrapers (see Chapters 4 and 5, this volume). Lamps may have been used by builders or grave robbers as a source of light, while digging tools made from qawadis and large bowls or jars could have been used to build the graves or to plunder them. It is not possible to establish when these graves were looted.

\section{Conclusions}

According to David and Salvatori, "the main features of the ceramic productions established during the post-Meroitic period - the dichotomy of the former Meroitic kingdom with a gradual rise of the handmade tradition in the south, while the north promotes wheel-made mass productionlay the foundations for the situation of the subsequent medieval period" (David and Salvatori 2019, 19).

Meroitic traditions are still evident in the El-Zuma assemblage, which includes vessels of the Meroitic period, but with a limited range of forms and decoration. Imported pottery occurs sporadically, and local production is predominant. Fineware, which was common in the Meroitic period, is not represented in the El-Zuma assem- 
blage. New forms appeared in the Transitional and postMeroitic periods and remained in use until the Christian period.

In the Early Meroitic repertoire, wheel- and handmade wares were limited. They mainly comprised bowls of different profiles and jars, and black ware was more common. Decoration consisted mostly of impressed dots, often in a geometrical design, and also reflected the savannah environment, with depictions of animals, birds, plants and human figures indigenous to the region. In the Classic Meroitic period, or shortly afterwards, wheel-made painted pottery dominated a widespread area-between the First and the Sixth Cataracts - and was produced in major Meroitic centres, such as Meroe itself, Musawwarat es-Sufra and Faras. Many motifs used in painted decoration were derived from earlier traditions, with continued use of dotted-impressed motifs and representations of human figures, animals, birds, reptiles, plants, and some ceremonial scenes, despite northern inspiration from Roman Egypt (Mahmoud El-Tayeb 2010c, 912).

In the Early Makurian period wheel-made pottery is still predominant in the El-Zuma assemblage, but the difference in quantity between wheel-made and handmade pottery is not big [Diagram 6.2]. There is also a visible decrease in the amount of painted pottery. There are only a few examples of painted cups, goblets, and small bowls, and the design repertoire is limited to simple geometrical patterns, with no depictions of animals, birds, plants, or human figures. Looking at the maps presented above, it is evident that the influence of the northern (see, for example, Figs 6.6, 6.12, 6.14) and southern traditions (see, for example, Figs 6.4, 6.8, 6.10) meet in the Dongola Reach, and this is clearly reflected in the pottery assemblage. Some forms, such as goblets and bottles, as well as imported pottery, originated in Lower Nubia. Some represent an Upper Nubian tradition, among them beer jars, cooking vessels, slipped and burnished cups and bowls, which seem to have originated in the Dongola Reach region. The imports from the north, from Egypt or Lower Nubia, were not significant, and most of the pottery discovered at the cemetery is of local production [Diagram 6.1]. It seems that the Early Makurian period marked a decline in imported pottery, which was more common during the Meroitic period.

Looking at the pottery from the El-Zuma cemetery, we can identify a basic set of vessels that was placed in the graves [Table 6.1 and Diagram 6.3]. This set consists of slipped and burnished bowls, cups and beer jars, cooking pots and bowls. They are present in all types of tumuli. The distribution of pottery types within individual types of tumuli [Table 6.2 and Diagram 6.4] shows that cups, small bowls, and jars were very common, especially in type II tumuli. Although they were less abundant in type I mounds, they were still present in large quantities. Imported vessels were noted mainly in tumuli of types I and II. In type III tumuli, which were the most modestly furnished and smallest graves, the majority of the excavated pottery consisted of vessels from the basic repertoire: cups, bowls, and jars. We should also note that certain forms survived from the Meroitic period and remained in use, the original Meroitic design having been slightly modified in some cases, but new forms also appeared in the Early Makurian period and survived into the Christian period (see Chapter 6.1). Analysis of human bones suggests that this necropolis was in use during AD 350-6oo, in the post-Meroitic and Early Makurian periods (see Volume I, Chapter 7). The pottery, especially the presence of Dongolan amphorae (found in situ), suggests that the site was still in use at least until pottery production began at Old Dongola (Pluskota 2001, 2005).

As mentioned in volume I, the El-Zuma cemetery was attributed to a specific period between the fall of the Meroitic state and the rise of the Kingdom of Makuria, and our knowledge of this time is limited. Changes in political systems were often not synonymous with the usually slower and more gradual changes that took place in everyday life and religious practices in different parts of Ancient Nubia.

The term "Early Makurian period" was introduced by Mahmoud El-Tayeb in the light of discoveries made at the El-Zuma necropolis, where Meroitic traditions continued and mingled with Makurian traditions. Evolution and gradual changes are evident in the construction of the tombs at El-Zuma, from the simple structures of type III tumuli, which are rooted in earlier Meroitic traditions, to the emergence of a new type of grave with a U-shaped shaft and additional side chambers (tumuli types I and II). Meroitic traditions are still evident in the pottery and personal adornments (see also Volume III, Chapters 2-8), and coexist with the beginnings of Makurian culture. Pottery ascribed to Makurian times, such as Dongolan amphorae, or jewellery such as the crosses discovered at the El-Zuma cemetery, may have been precursors of the Makurian tradition. Dates obtained from human teeth recovered from three tumuli:T.18-AD 83-311; T.21-AD 387-538; and T.24-AD 264-535 (see Volume I, Chapter 7), and the Dongolan pottery discovered in T.26 suggest that this necropolis was in use from the Late Meroitic to the advent of the Makurian period.

However, we should be careful with the analysis of the archaeological material from this period. Robber activity 


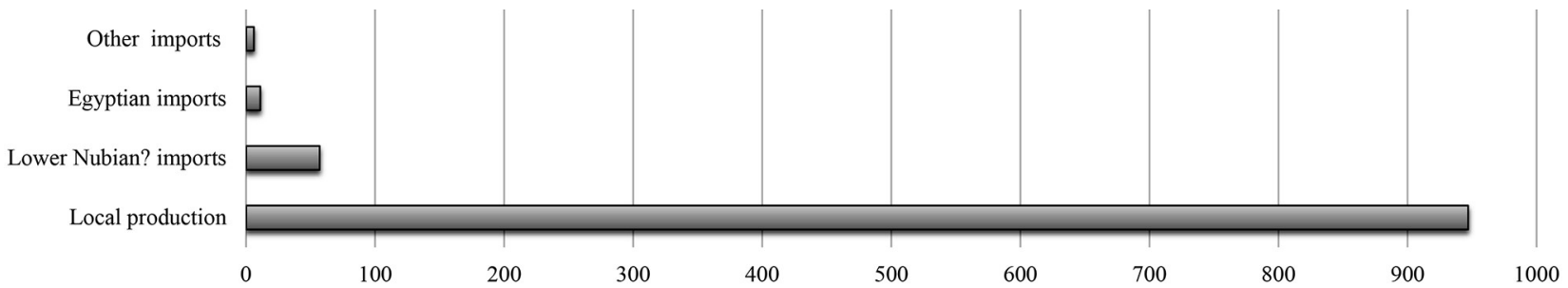

DIAGRAM 6.1 Graph showing the representation of local and imported pottery in the whole El-Zuma ceramic assemblage MADE BY E. CZYŻEWSKA-ZALEWSKA

\section{Wheel-made \\ Handmade}
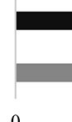

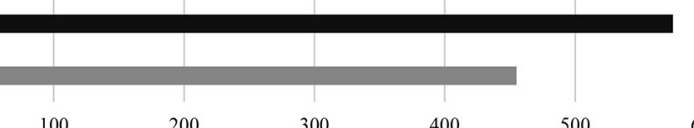

DIAGRAM 6.2

Graph showing the proportion of wheel-made and handmade pottery in the whole El-Zuma ceramic assemblage

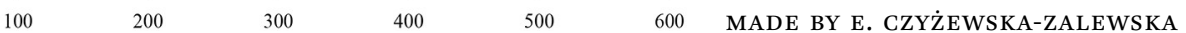

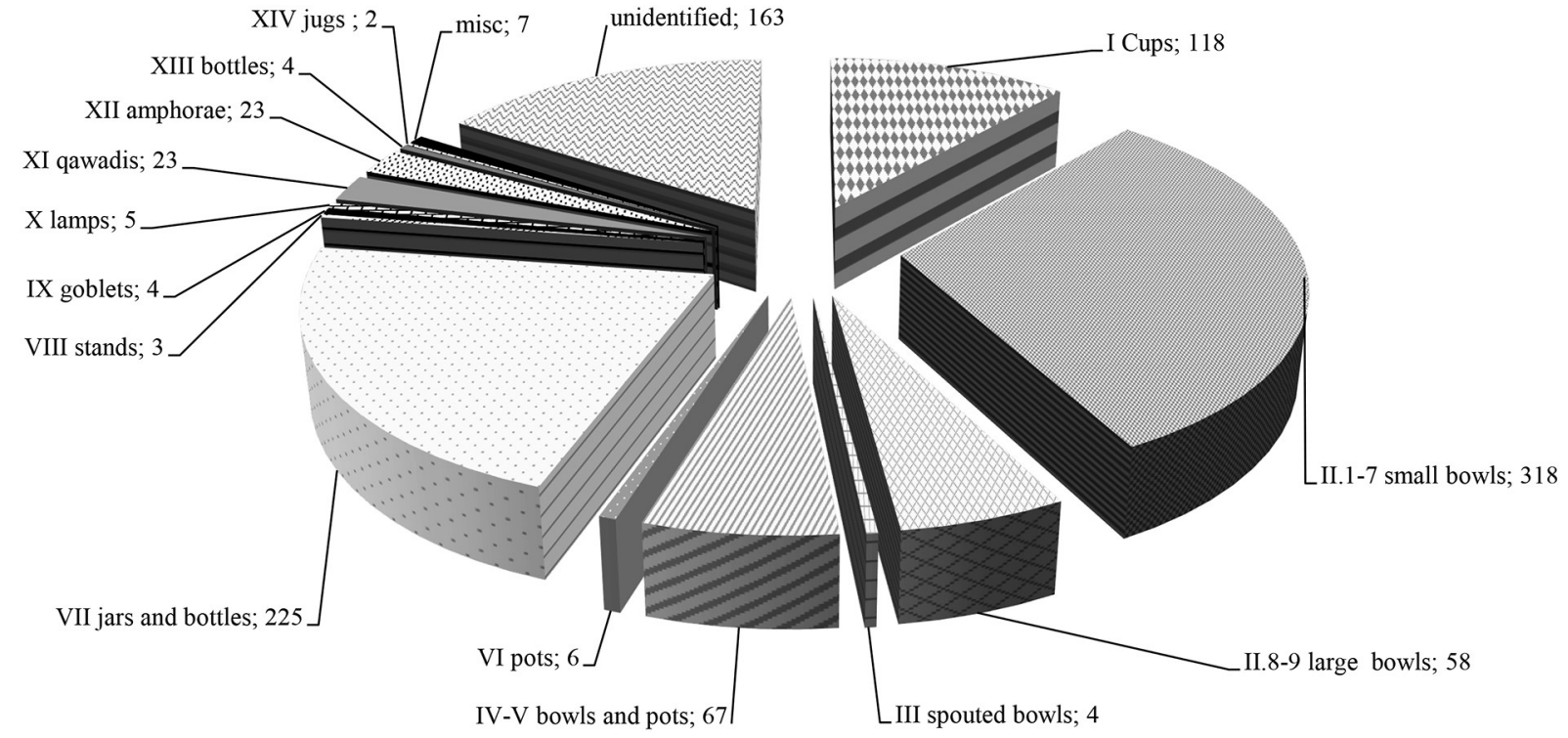

DIAGRAM 6.3 Pie chart showing the number of individual types of pottery in the whole El-Zuma ceramic assemblage

MADE BY E. CZYŻEWSKA-ZALEWSKA

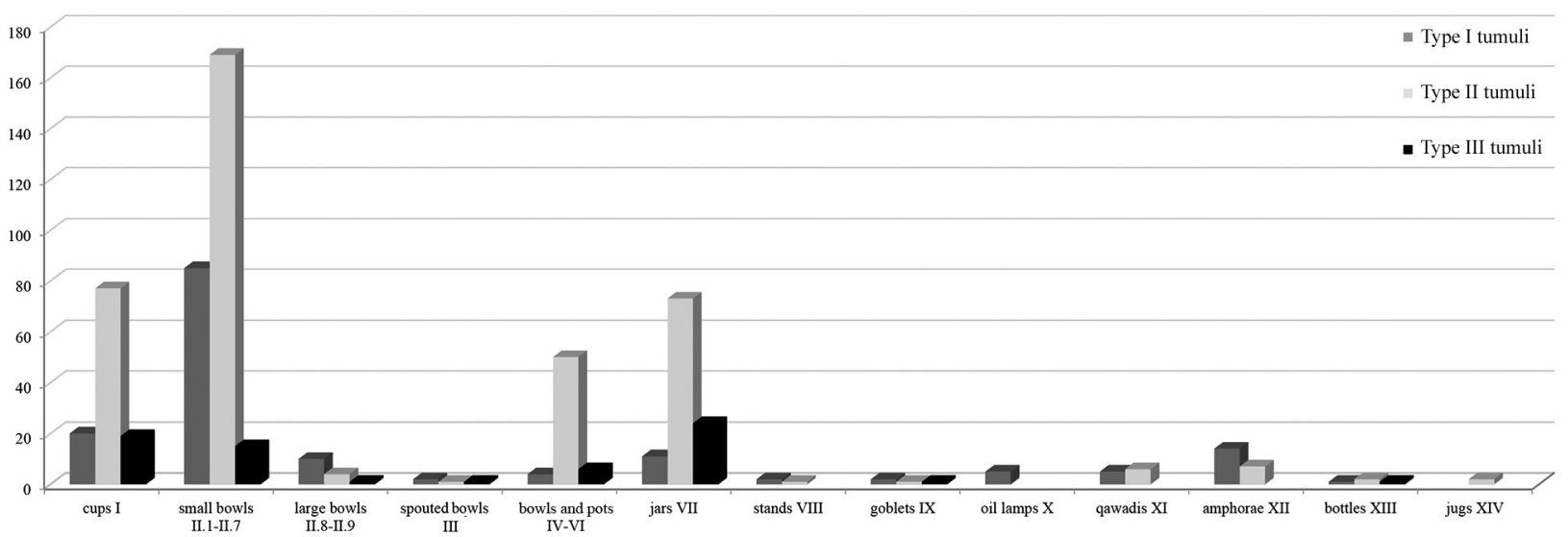

DIAGRAM 6.4 Graph showing the number of specific types of pottery found in individual types of tumuli MADE BY E. CZYŻEWSKA-ZALEWSKA 
TABLE 6.1 Total registered pottery vessels in the El-Zuma assemblage

\begin{tabular}{lr}
\hline & All registered objects \\
\hline I Cups & 118 \\
II.1-7 small bowls & 318 \\
II.8-9 large bowls & 58 \\
III spouted bowls & 4 \\
IV-V bowls and pots & 67 \\
VI pots & 6 \\
VII jars and bottles & 225 \\
VIII stands & 3 \\
IX goblets & 4 \\
X lamps & 5 \\
XI qawadis & 23 \\
XII amphorae & 23 \\
XIII bottles & 4 \\
XIV jugs & 2 \\
misc & 763 \\
unidentified & 1030 \\
total & \\
\hline Handmade & 455 \\
Wheel-made & 575 \\
\hline Local production & 647 \\
Egyer Nubian? imports & \\
Other imports & \\
\hline & \\
& \\
&
\end{tabular}

COMPILED BY E. CZYŻEWSKA-ZALEWSKA

also makes the analysis of artefacts and skeletons more difficult, as it resulted in their being removed from their original contexts, and often tombs remained open for a long time, leaving the material exposed to external factors. This situation is evidenced by damage to the pottery in the form of bite marks left by rodents that probably gnawed the sherds to wear down their teeth [Fig. 6.17] (see also Volume I, Chapter 8). Such sherds were found mainly in the tunnels of the largest tumuli, which suggests that the tombs or tunnels were left open for quite some time.

Social variation is also apparent at the El-Zuma necropolis. The differentiation of the grave goods in the three types of tumuli reflects the grave occupant's status in the local hierarchy. A range of personal adornments, including jewellery and royal regalia such as that noted at Ballana and Qustul, was found primarily in type I graves, whilst examples of jewellery recovered from graves of types II and III were less opulent (Volume III, Chapters ${ }_{2-5}$, Volume I, Final Discussion). Better and more varied types of meat were found in type I graves, whilst the other two grave types contained fewer varieties and smaller quantities of meat (see Volume I, Chapter 8). Larger numbers and greater varieties of vessels were found in type I tumuli, which also featured imported pottery. Although type II tumuli sometimes contained significant quantities of ceramics, the types of vessels were far less diverse and imports were noted only sporadically. The sets of pottery found in type III tumuli were very modest, comprising several vessels of two or three types. We can conclude that the largest tombs (types I and II) were the most elite, whilst the smallest ones were the graves of individuals ranked lower in the social hierarchy, and that El-Zuma was the cemetery of the Early Makurian elite. 


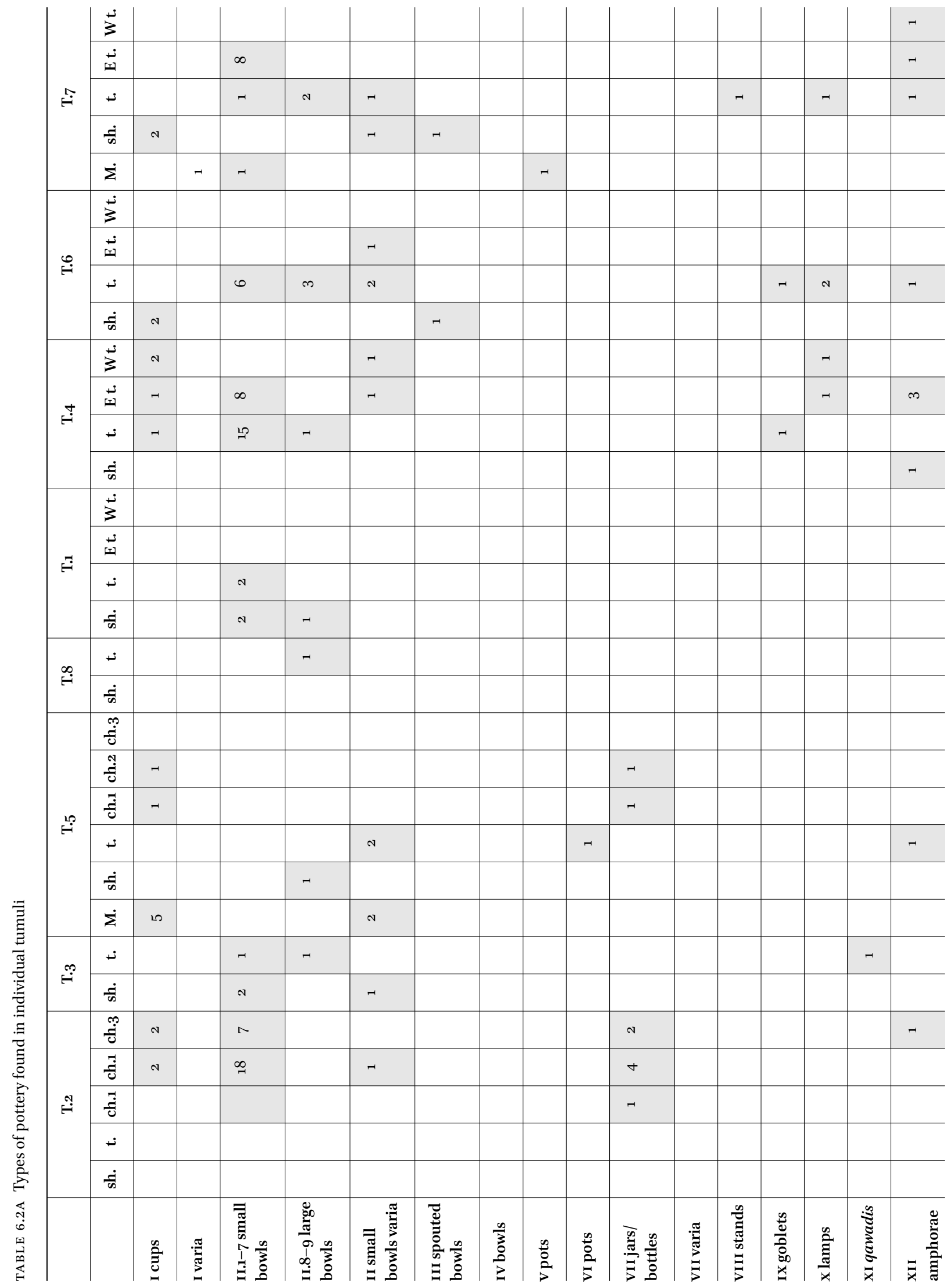




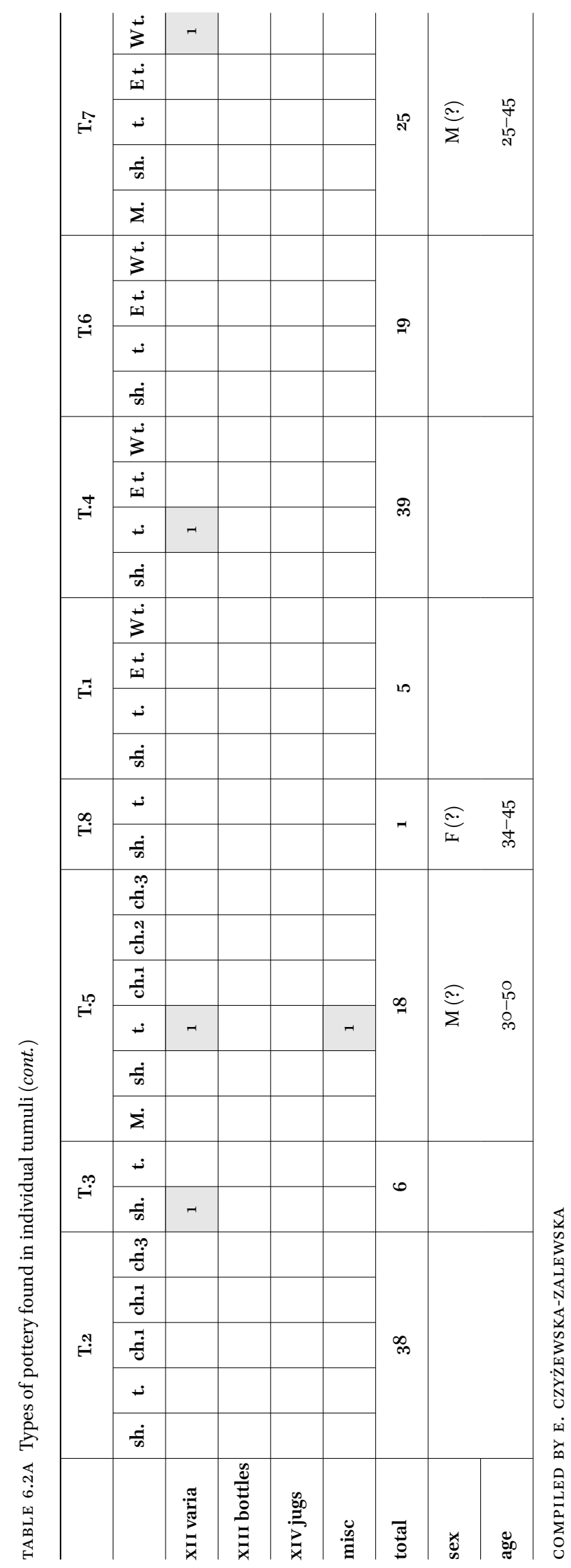




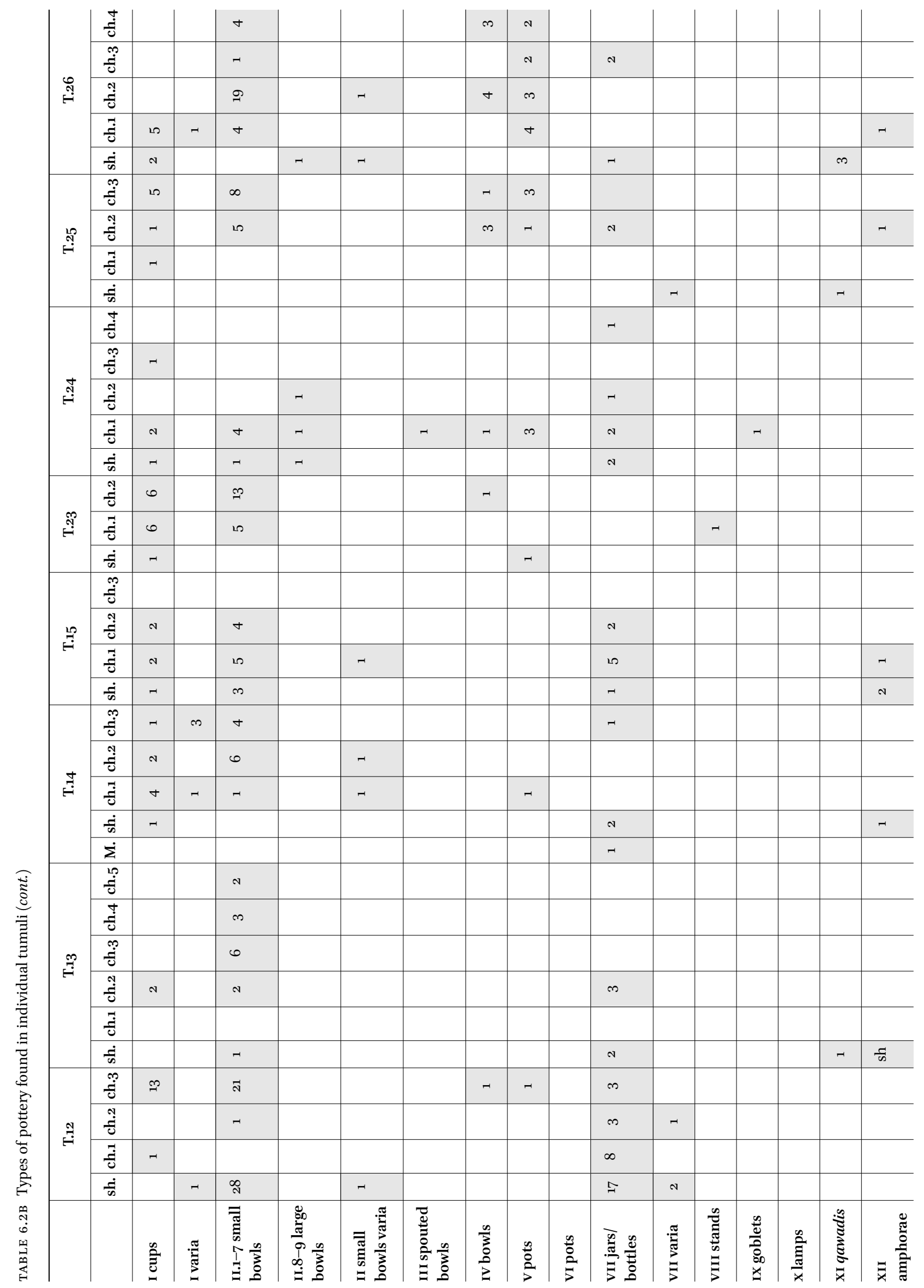




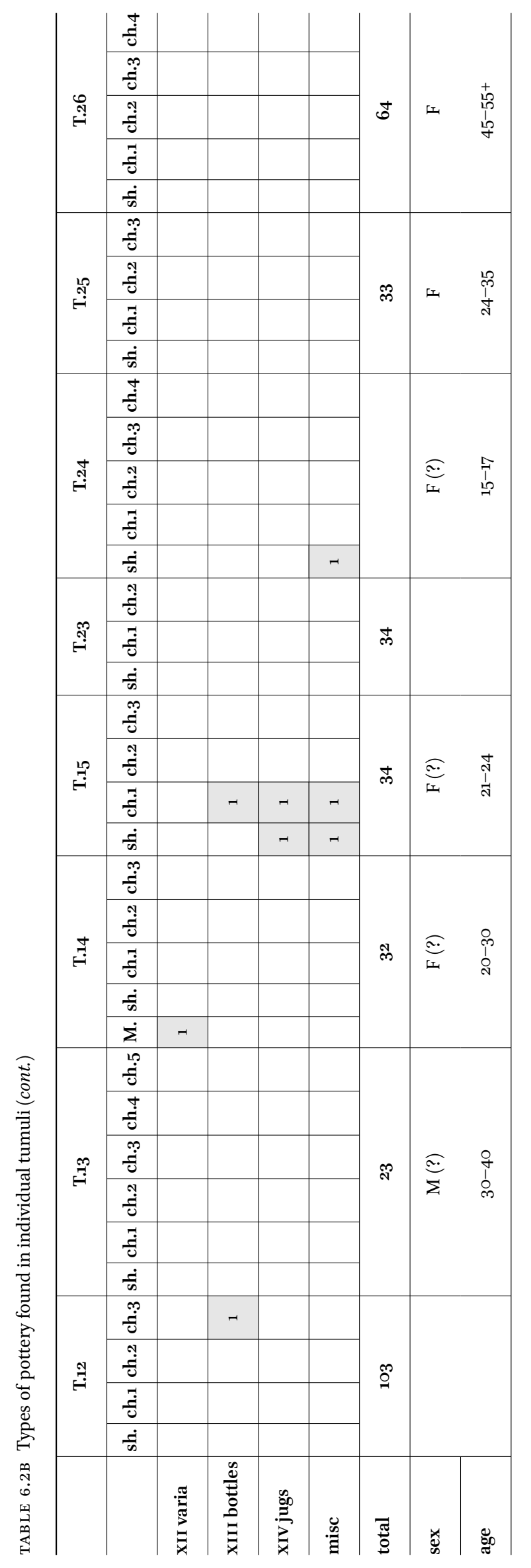




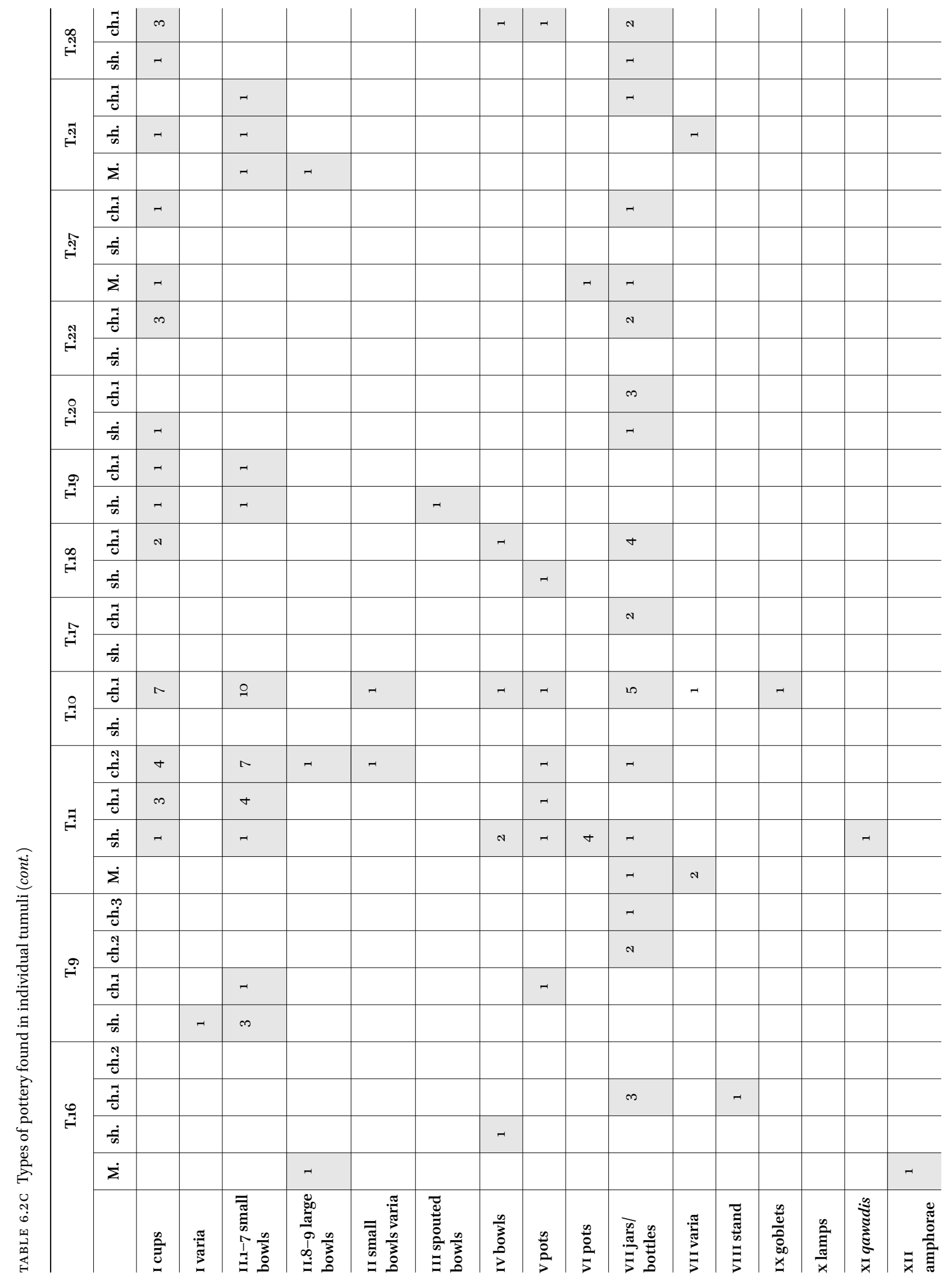




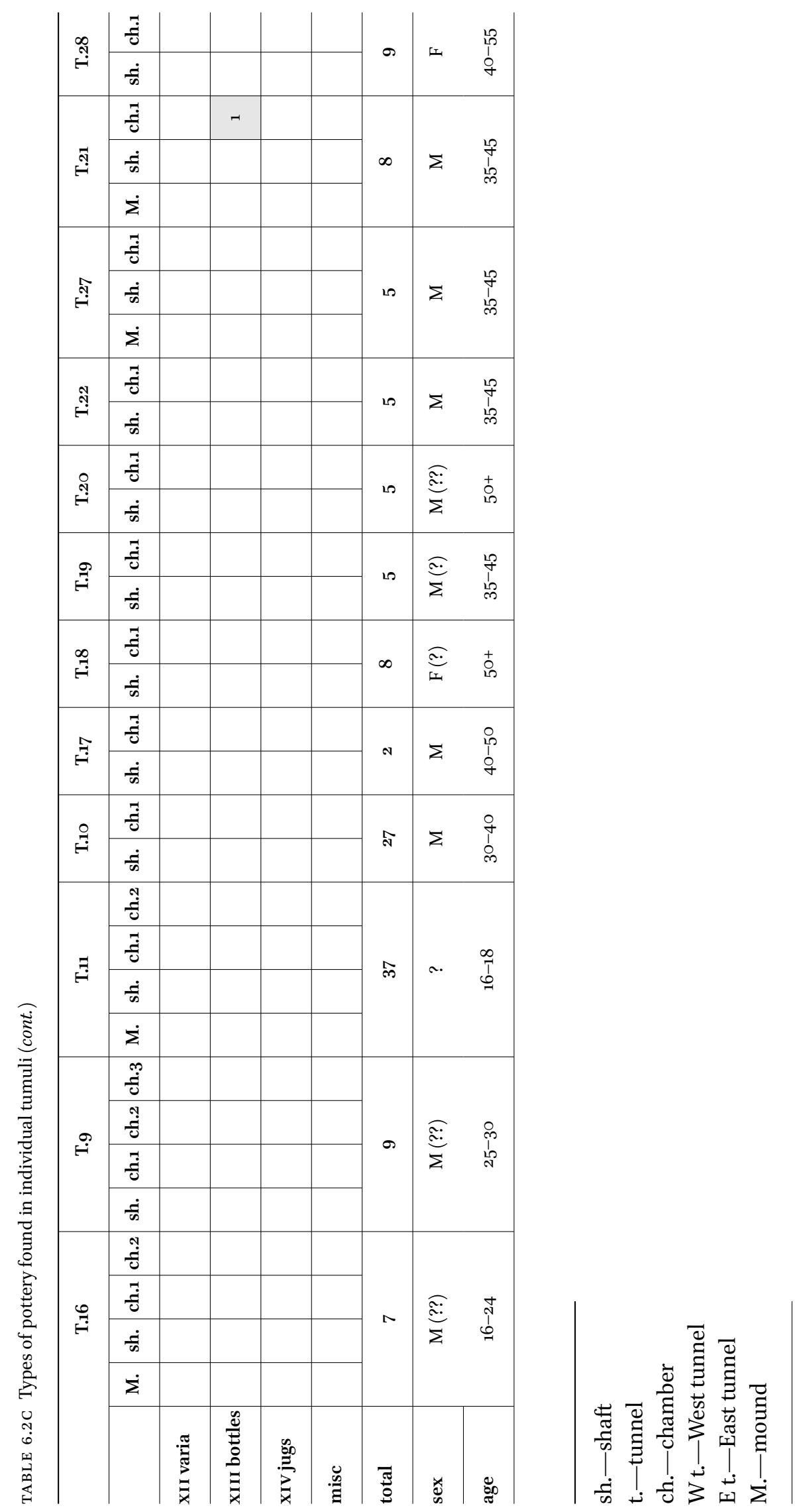




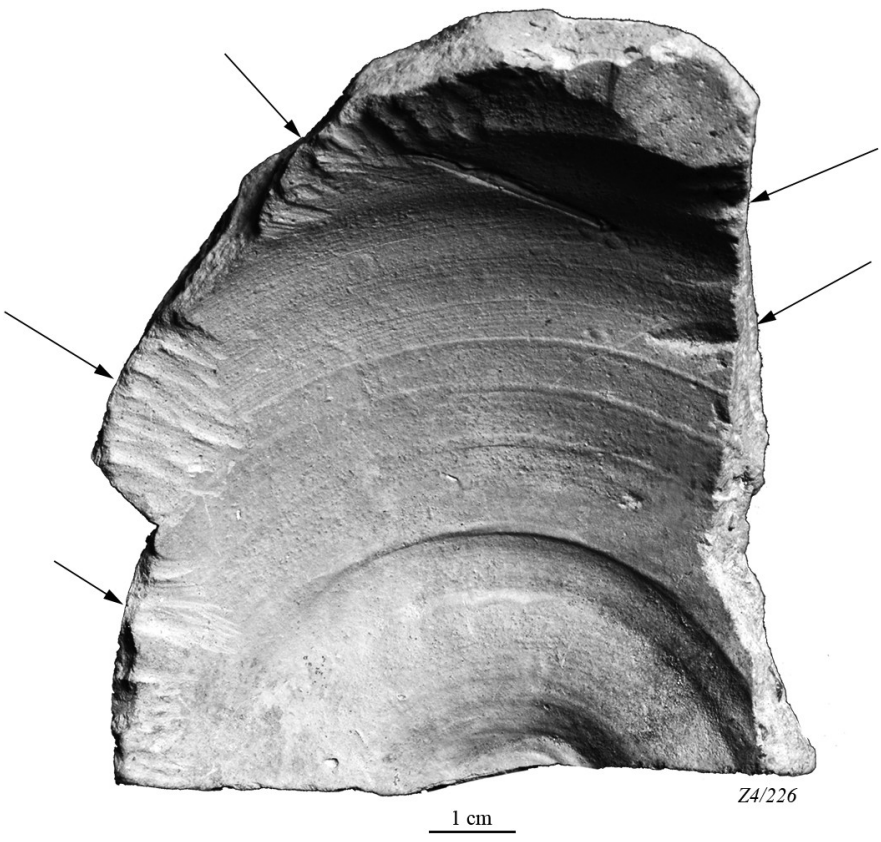

GURE 6.17

Rodent tooth marks on a pottery sherd PHOTO BY A. KAMROWSKI 